Portland State University

PDXScholar

$1-1-1983$

\title{
The paleolimnology of Bull Run Lake: disruption and stability in a natural system
}

Richard Brian Raymond

Portland State University

Follow this and additional works at: https://pdxscholar.library.pdx.edu/open_access_etds Let us know how access to this document benefits you.

\section{Recommended Citation}

Raymond, Richard Brian, "The paleolimnology of Bull Run Lake: disruption and stability in a natural system" (1983). Dissertations and Theses. Paper 98.

https://doi.org/10.15760/etd.98

This Dissertation is brought to you for free and open access. It has been accepted for inclusion in Dissertations and Theses by an authorized administrator of PDXScholar. Please contact us if we can make this document more accessible: pdxscholar@pdx.edu. 
THE PALEOLIMNOLOGY OF BULL RUN LAKE:

DISRUPTION AND STABILITY IN A

NATURAL SYSTEM

by

RICHARD BRIAN RAYMOND

A dissertation submitted in partial fulfillment

of the requirements for the degree of

DOCTOR OF PHILOSOPHY

in

ENVIRONMENTAL SCIENCE

AND

RESOURCES

Portland State University

1983 
TO THE OFFICE OF GRADUATE STUDIES AND RESEARCH:

The members of the Committee approve the

dissertation of Richard Brian Raymond presented July $15,1983$.

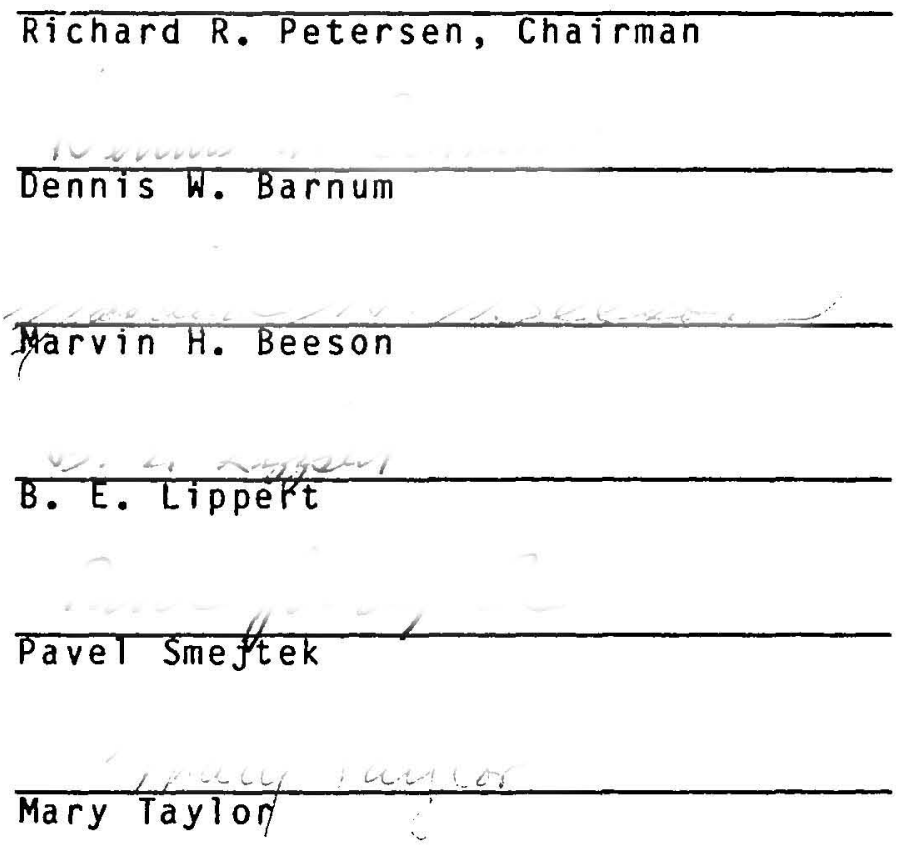

APPROVED :

Robert 0. Tinnin, Coordinator, Environmental Science Stantey E. Rauch, Dean of Graduate Studies and Research 


\begin{abstract}
AN ABSTRACT OF THE DISSERTATION OF Richard Brian
Raymond for the Doctor of Philosophy in Environmental

Science and Resources presented July 15, 1983.
\end{abstract}

Title: The Paleolimnology of Bull Run Lake:

Disruption and Stability in a Natural System.

APPROVED BY MEMBERS OF THE DISSERTATION COMMITTEE:

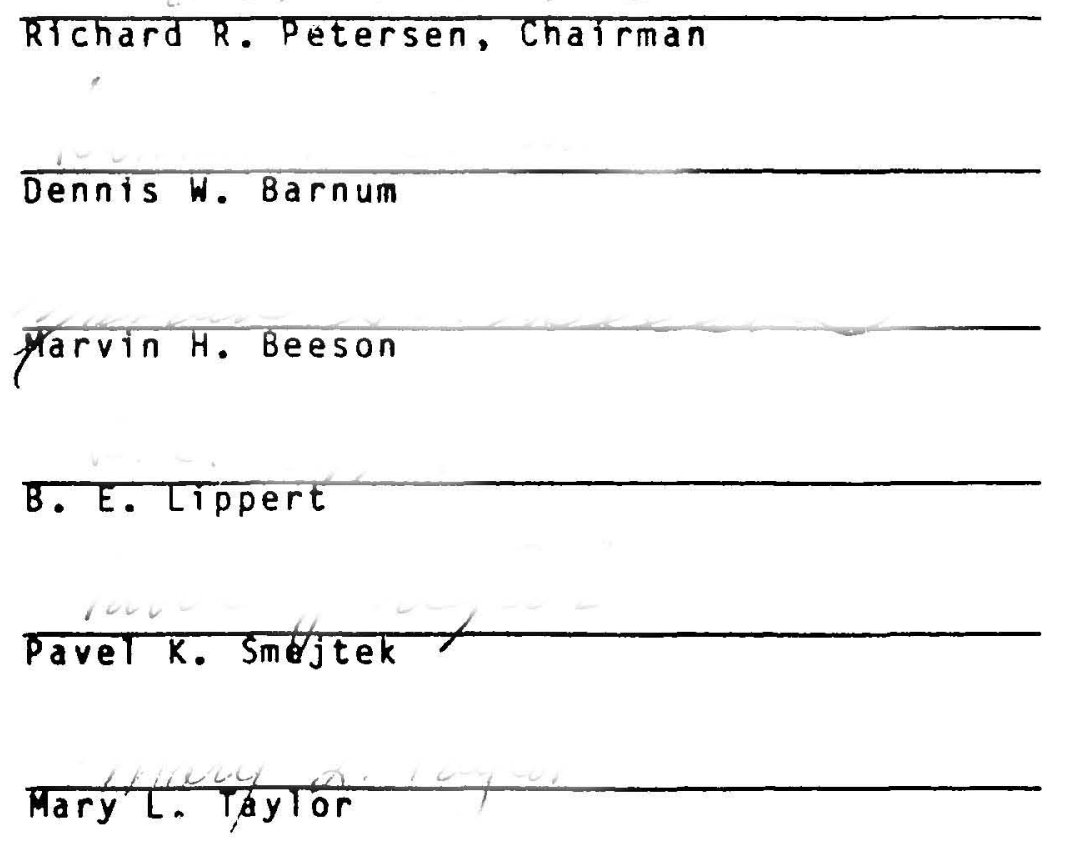

Detafled analysis of the physical, chemical, pollen and diatom stratigraphy of sediment cores from Buil Run Lake, Oregon reveals that the lake has been 
subject to repeated episodes of disruption by volcanic ash fall, fire and other disturbance over the past 4300 years. With the exception of fire, these disruptions have not resulted in long term changes in the watershed or in the characterstics of Bull Run Lake.

A major fire in the watershed about 750 years ago altered the vegetation. Since that time the forest has been returning to its former condition. 


\section{DED ICATION}

To Jeanne, who made it possible. 


\section{ACKNOWLEDGEMENTS}

I thank the faculty of the department of Biology for providing access to facilities and equipment, and the members of my committee for guidance throughout my work. I especially thank Dr. Richard Petersen for his guidance and counsel, Dr. Marvin Beeson for his patient introduction to the concepts of geochemistry, Dr. Robert Tinnin for many discussions of related and unrelated topics, and Dr. Richard Forbes for his critical review of the original manuscript.

I thank the staff of the Quaternary Research Center of the University of Washington for loaning me reference specimens from their pollen collection, and for guiding my initial efforts in pollen identification. Dr. Estella Leopold, Cathy Barnosky, and Rudy Nickman provided invaluable assistance.

My special thanks to James Sweet for assistance and companionship in the field, in the lab, and in many predawn hours at the microscope.

This work was supported in part by grants from the City of Portland, the U. S. Forezt Service, Portland State University, and the Mazamas. 


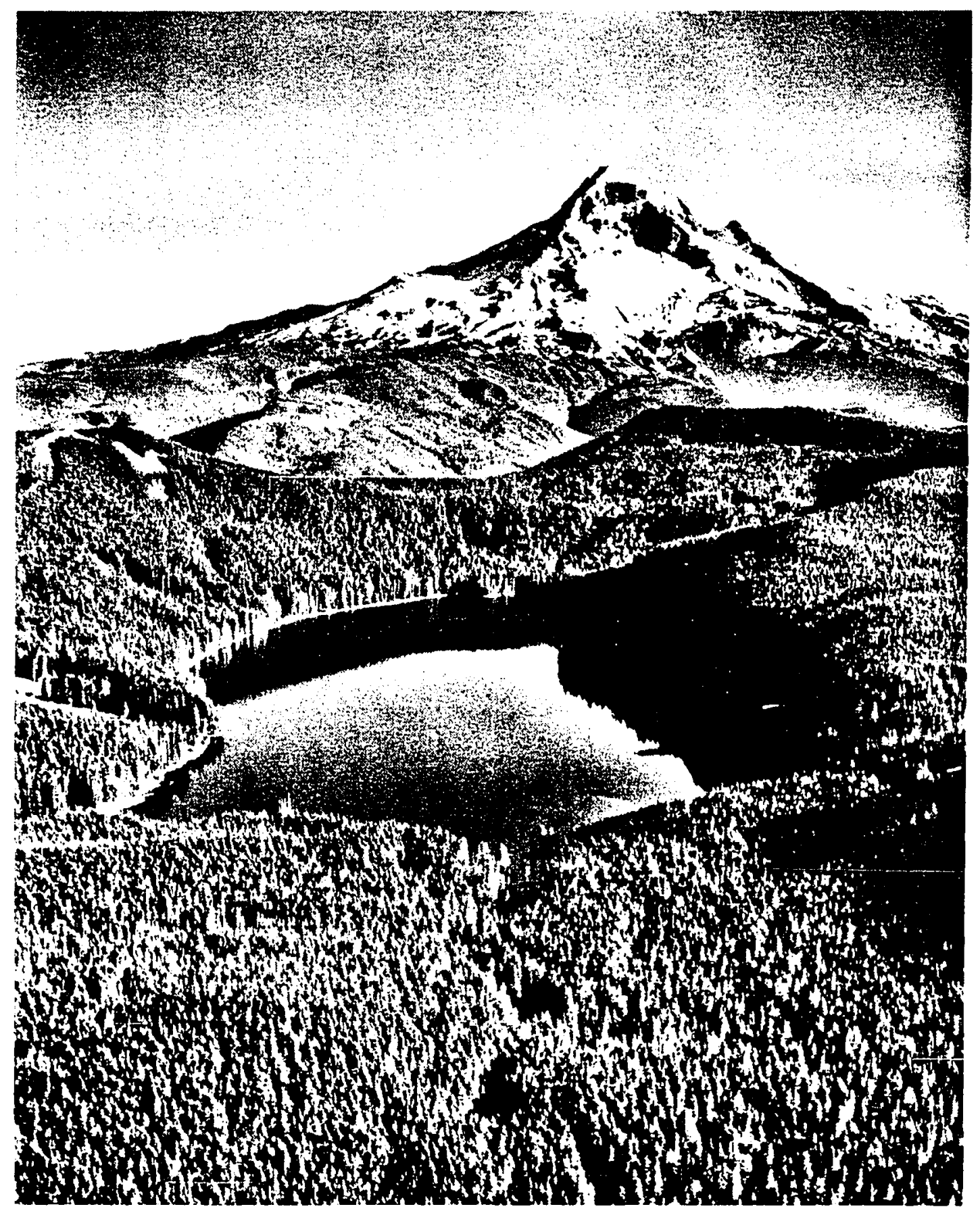

Frontispiece. Looking east toward Bull Run Lake with Mt. Hood in the background. (Photo courtesy of the U.S. Forest Service.) 


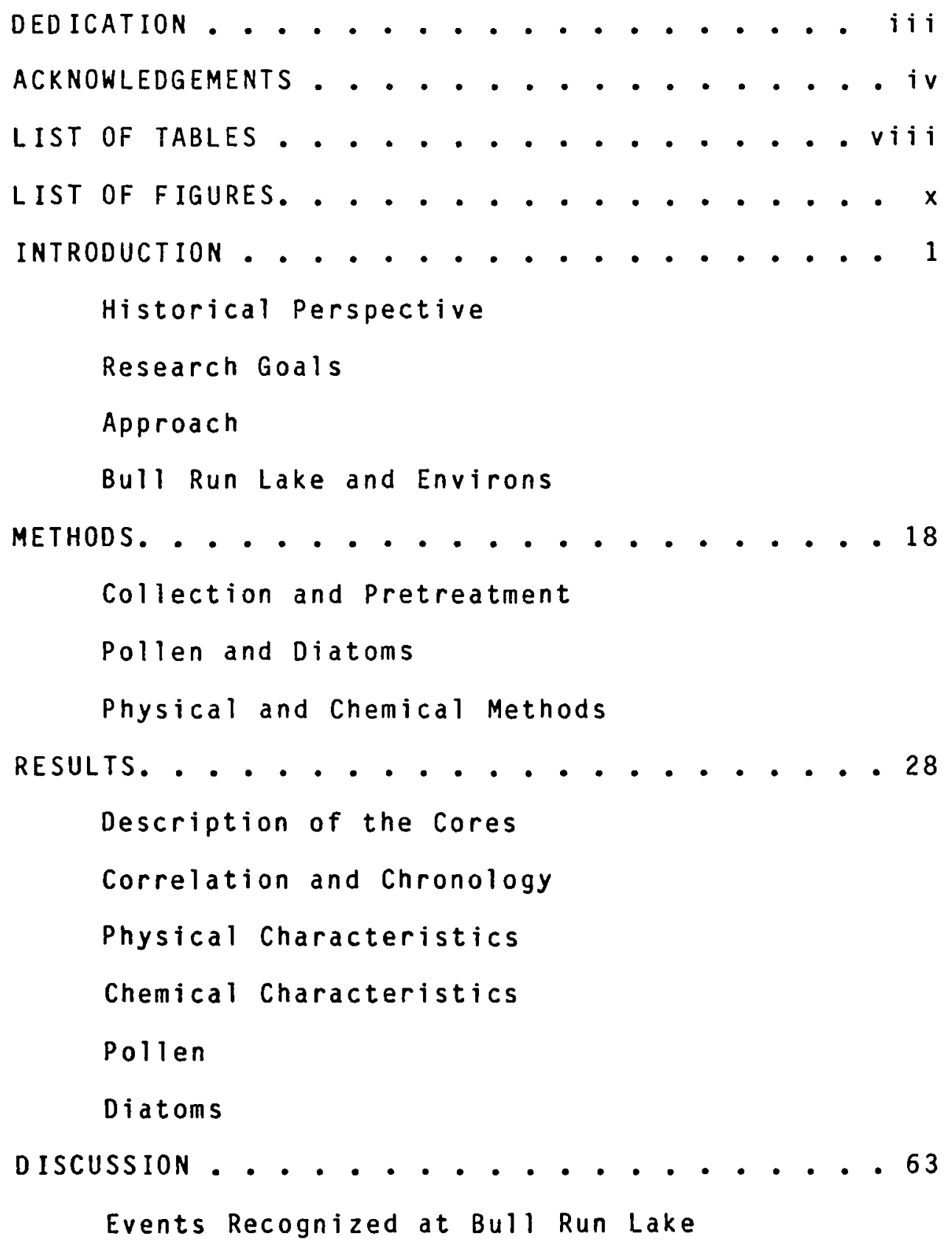




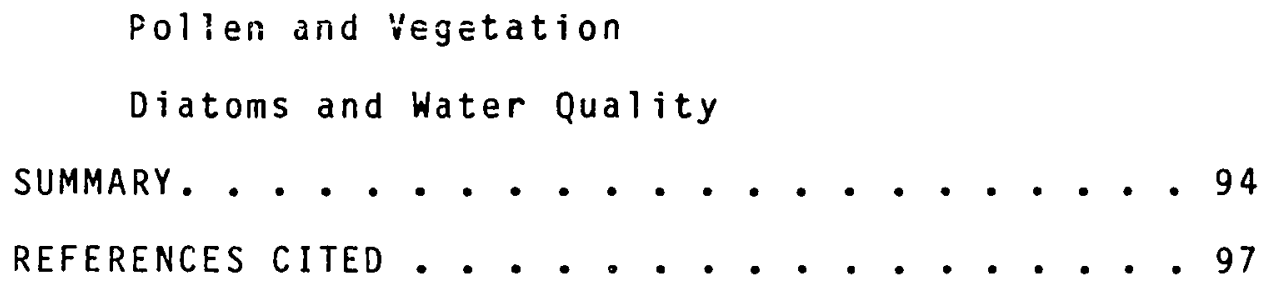




\section{LIST OF TABLES}

I Morphology and Chemistry of Bull

Run Lake.............. 11

II Bull Run Phytoplankton . . . . . . 13

II Vegetation in the Bull Run Lake

Basin............ . . 15

IV Concentration of Selected Elements in

Volcanic Ash Samples from Some Cascade

Range Volcanoes...... . . 30

$\checkmark$ Stratigraphy of Bull Run Lake Sediment

Cores..... . . . . . 32

VI Carbon-14 Dates of Bull Run Lake Core

BRL - 19............. 34

VII Calculated Ages for Various Features in

Bull Run Lake Cores...... . . 37

VIII Basic Statistics for Gravimetric Data. . 42

IX Results of Carbon Analysis of Bull Run

Lake Sediment . . . . . . . 43

$x$ Correlation Matrix of Element Data...47 
Plant Taxa Identified from Pollen in

Bull Run Lake Sediment. . . . . 55

XII Diatoms and other Algae Identified in

Bull Run Lake Sediment..... . 60

XII Trace Element Concentration for

Various Rocks in the Vicinity of

Bull Run Lake... . . . . . . 65

XIV Parameters Greater Than the 75th Per-

centile or Less Than the 25th

Percentile... . . . . . . 68

XV Historic Events Which May Have

Influenced Bull Run Lake. . . . . 71

XVI Element Concentration of Mt. St.

Helens Tephra and Bull Run Lake

Sediment. . . . . . . . . . 73 


\section{LIST OF FIGURES}

F IGURE

1. Bull Run Lake Vicinity Map. . . . . . 7

2. Bathymetric Map of Bull Run Lake. . . 12

3. Vegetation Map of Area Around Bull

Run Lake.............. 14

4. X-radiography of Bull Run Lake Sediment

Core BRL-1............. 31

5. Carbon-14 Age Versus Depth........35

6. Results of Gravimetric Analysis of Bull

Run Lake Sediment. . . . . . . . 39

7. Density of Bull Run Lake Sediment ... 40

8. Ratio of Water Content to Loss on

Ignition for Bull Run Lake Sediment. . 41

9. Concentration of Elements in Bull Run

Lake Sediment. . . . . . . . . . 45

10. Element Concentration in Bull Run Lake Sediment . . . . . . . . . . 46

11. Pollen Concentration Diagram from Bull

Run Lake............ 54 
12. Diatom Concentration Diagram from Bull

Run Lake... . . . . . . . 59

13. Number of Parameters Beyond the 25th and 75th Percentile... . . . . 66

14. Plot of Thorium vs. La/Yb for several Northwest Volcanoes. . . . . . 72

15. Smoothed Curve of Total Pollen Concentration from Bull Run Lake •. 85

16. Smoothed Curve of Total Diatom Concentration from Bull Run Lake •. 88

17. Ratio of Two Forms of Cyclotella stelligera from Bull Run Lake. . . 92 


\section{INTRODUCT ION}

The Bull Run River watershed supplies all the municipal water for the city of Portland and many of the surrounding communities comprising, in total, approximately one third of the population of the state of Oregon. This water source is unique in the United States for the degree of protection afforded it, the directives governing its management, and the degree of public input provided for consideration in mangement planning. The watershed is managed through the cooperative efforts of the City of Portland and the U.S. Forest Service, in consultation with a citizens advisory committee.

The Bull Run River is located $50 \mathrm{~km}$ east of Portland, Oregon. The river's watershed includes approximately 43,000 ha of National Forest lands with minor amounts owned by the city and by private parties. Within the watershed are Bull Run Lake, source of the Bull Run River, several smaller tributary streams, and two man-made water storage reservoirs.

In 1892 President Benjamin Harrison signed the Bull Run Timber Reserve proclamation (18 USC 1907, 1892) which set aside the Bull Run area as a public reservation, defined its boundaries, and reserved the 
area from public entry (Pearlman, 1978; Raymond, 1980).

In 1904 Congress passed the Bull Run Trespass Act (18 USC 1862) which strengthened the protected status of the area, and excluded from the Reserve all persons except forest rangers and water bureau personnel.

The Forest Service began logging in the watershed in the late 1950's. In 1973 a suit was filed (Miller, 1973) to stop this logging. A Circuit Court decision against the Forest Service in 1976 (Burns, 1976) caused reconsideration of the Trespass Act.

The Bull Run Management Act, PL 95-200 (91 Stat 1425), was passed in 1977 in response to the District Court decision. The Law repealed the 1904 Trespass Act, and established the Bull Run Management Unit by revising the boundaries of the former Bull Run Reserve. Public Law 95-200 permits logging, and specifies that the Bull Run Management Unit will be managed by the U.S. Forest Service, under the laws governing the National Forests, as a municipal watershed with the primary purpose of producing pure, clear, potable raw water for Portland use. The Law also establishes guidelines for coordination between the forest Service, the city, and their advisors in planning and managing the watershed. The basic planning document is the Bull Run Final Environmental Impact Statement (USDA, 1979).

PL 95-200 charges the Forest Service to manage 
the Bull Run watershed in a manner that will ensure that "no significant adverse effect" is produced in the quality and quantity of water flowing from the watershed. Water quality is to be compared with baseline data collected from 1967 to 1975, a period considered by some to be insufficient to determine significant variations (Averret et al., 1980). Because the determination of significance is central to the management plans for the watershed, it is vitally important to be able to ascertain with confidence whether a given observed change is or is not significant.

In addition, naturally occurring events, such as fire, climatic variations and other natural phenomena are specifically excluded from consideration in determining the current or historical water quality. It is important to have information about the history of occurrence and effects of such events. Without long term information, it is not possible to assess completely the significance and importance of current impacts (Davis and Norton, 1978).

Research Goals

The purpose of this study is to present a record of events in and around the Bull Run watershed for a sufficient time in the past to permit conclusions to be 
drawn concerning the stability of the system, and to permit judgements to be made concerning the significance of particular changes in water quality in the future.

This record has been developed by paleolimnological analysis of sediments from Bull Run Lake. Bull Run Lake was selected because it lies within the Bull Run Management Unit, is morphologically suited to develop an undisturbed sedimentary record, and because the lake and its watershed have been little disturbed by human activity.

This dissertation will present a history of events affecting Bull Run Lake for the past 4500 years, identify some major disruptive events that have occurred in the watershed dising this time, and relate these events to vegetation changes in the watershed and water quality in Bull Run Lake.

\section{Method of Approach}

Because lake sediment accumulates sequentially on the bottom of a lake, it preserves a continuous record of the conditions over the time of accumulation. By recovering and analyzing these sediments, it is possible to reconstruct the history of the lake, identify major events occurring near the lake, and assess the impact these events have had on the lake. 
Paleolimnological methods have been applied successfully to lakes throughout the world, and have been used to develop surprisingly detailed understandings of the past. Natural changes in lakes have been documented (Deevey, 1942), and have led to the understanding that lakes respond in complicated ways to changes in the environment (Wetzel, 1975, P.626).

The effect of human influence on lakes has been demonstrated repeatedly by paleolimnological methods. Changes due to ancient roadbuilding in Italy (Hutchinson, 1970), the impact of Mayan urbanization in Mexico (Deevey et al., 1979), the impact of early settlement, logging and iron mining in Minnesota (Bradbury and Waddington, 1973), increases in sedimentation due to logging in Indiana (Crisman and Whitehead, 1975), changes in climate and water budget (Bradbury, 1971), in nutrient inputs (Bortleson and Lee, 1972), and the effects of cultural eutrophication (Davis and Norton, 1978; Petersen, 1975; Birks et al., 1976; Alhonen, 1979; Davis and Larson, 1976; Meyerhoff, et al., 1978) have been documented.

Pollen analysis has been used to develop information on past climates around the world (Faegri and Iverson, 1975; Livingstone and Kendal1, 1969; Davis, 1965; Moore and Webb, 1978; Bernabo, 1982) 
including the USA (Deevey, 1939) and the Pacific Northwest (Hansen, 1947; Heusser, 1976; Barnosky, 1981).

Pollen analysis, combined with charcoal analysis of sediments, has been used to develop the fire history of forested regions in Minnesota and Wisconsin (Swain, $1973 ; 1978)$, and also to elucidate the continuing cycle of deforestation, burning, agriculture and reforestation during the past 6000 years in Finland (Tolonen, 1978). Pollen analysis has also been useful in documenting changes in land use in the eastern United States (Brugam, 1978).

The literature indicates that an event sufficient to cause a change in the water quality conditions in Bull Run Lake will have left a clear trace in the lake sediment. Thus, the study of the lake sediment can provide an additional source of data to document the extent and nature of natural variability of water quality conditions in the lake and watershed.

Bull Run Lake and Environs

Bull Run Lake is located on the west slope of the Cascade Mountains in Multnomah and Clackamas counties, Oregon (Figure 1.). It is approximately $14 \mathrm{~km}$ northwest of Mt. Hood, and $21 \mathrm{~km}$ southeast of Bonneville Dam on the Columbia River. The lake covers 


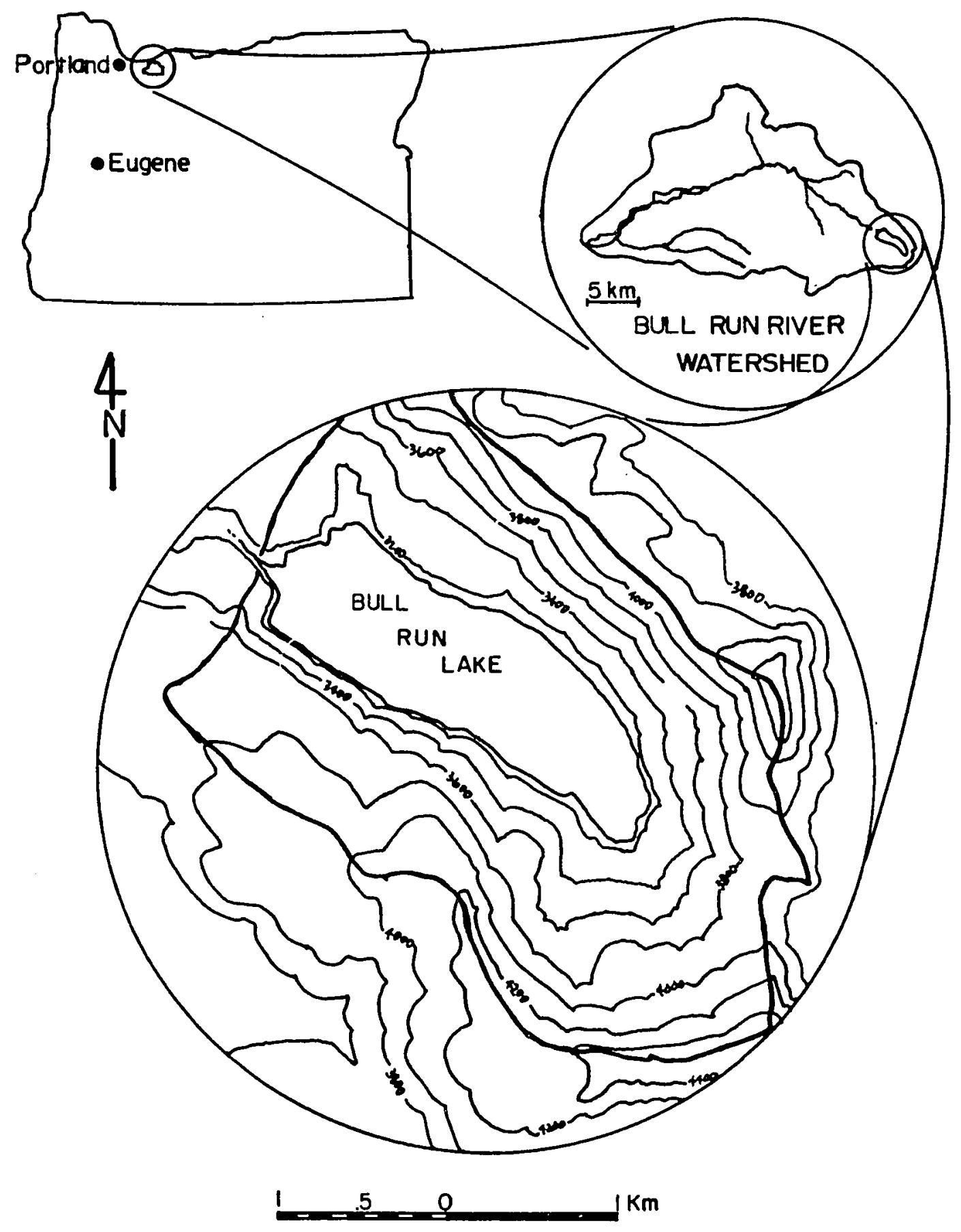

Figure 1. Bull Run Lake vicinity map. Heavy Tine denotes boundary of Bull Run Lake watershed. Elevations are in feet. 
parts of several sections of T.1S.,R.8E, Willamette Meridian. The outlet is located at latitude $45^{\circ} 27^{\prime} 39^{\prime \prime}$, longitude $121^{\circ} 50^{\prime} 41^{\prime \prime}$ (Schulters, 1975).

Bull Run Lake is surrounded on three sides by ridges with slopes of 30 to 60 percent (see frontispiece), increasing to greater than 60 percent on the northeast end of the lake. These ridges rise from the lake (elevation $968 \mathrm{~m}$ ) to about 1220 meters elevation. The highest point in the watershed is Hiyu Mountain at $1420 \mathrm{~m}$.

Wise (1969) describes the rocks surrounding Bull Run Lake as olivine basalt and olivine andesite of late Pliocene or early Pleistocene age. Wollenberg et al. (1979) map the rocks immediately surrounding Bull Run Lake as lower Pliocene basalts and andesites (90\% andesite) with the exception of the extreme eastern end of the lake which are described as Pleistocene basalts and andesites from vents satelite to Mt. Hood. The rocks which form the Bull Run Lake basin predate Mt. Hood volcano (Wise, 1969).

The basin in which Bull Run Lake lies was formed by Pleistocene glaciation (Beaulieu, 1974), but the nature of the natural dam on the west which forms the lake is disputed. Shannon and Wilson (1961) attributed the lake to a terminal glacial moraine, and the U.S. Forest Service (1972) described Bull Run Lake as 
filling a "cirque behind a classical terminal

moraine". Beaulieu (1974) however, states that

exposures in road cuts and along the exit channel from

the lake indicate that the dam forming the lake

consists of a series of flows of basaltic andesite.

The similarity of the weathered agglomerates and

breccias to glacial till, and a scattering of morainal

material on top of the volcanic material led to the

mistaken identification of the unit as a terminal

moraine (Beaulieu, 1974).

The material forming the western end of Bull Run Lake is very porous. The exit stream enters the ground a short distance from the lake and emerges about $1 \mathrm{~km}$ later to become the Bull Run River. There is also, or was in the past, significant seepage from the bottom of the lake. "Sinkholes" were noted in the lake bottom in 1917, and efforts were made by the Portland Water Bureau to stop the flow (Raymond, 1980).

The climate at Bull Run Lake is cool maritime with wet winters and dry summers. The mean annual temperature is $5.5^{\circ} \mathrm{C}$. The mean temperature in January is $-2.0^{\circ} \mathrm{C}$; in July it is $14.5^{\circ} \mathrm{C}$ (Franklin and Dryness, 1973). For the period from 1961 through 1967 average annual precipitation was $3125 \mathrm{~mm}$, much of it as snow which may accumulate to 6-9 $\mathrm{m}$. Approximately 6 percent of the annual precipitation falls in the period 
July through September (USDA, 1972). In $19763934 \mathrm{~mm}$ of precipitation was measured at the gage at the west end of Bull Run Lake.

Bull Run Lake is a deep, clear, low nutrient oligotrophic lake (Table I, Figure 2). The phytoplankton is sparse, less than 100 cells per $\mathrm{mL}$, and the species composition indicates an oligotrophic system (Hutchinson, 1967 p.365) (Table II).

The entire Bull Run Lake basin is covered with virgin conifer forest with the exception of a few areas of bare talus slope and talus shrub communities. The lake lies near the transition between the Isuga heterophylla vegetation zone (elevation 150-1000 m) and the Abies amabilis zone (elevation 1000 to $1500 \mathrm{~m}$ ) (Franklin and Dryness, 1973). Major forest trees of the Abies amabilis zone are Abies procera, Abies amabilis, and Tsuga heterophylla. Pseudotsuga menziesii is a minor component of the forest, found only below $1000 \mathrm{~m}$. Tsuga mertensiana is found occasionally at the higher elevations in the basin (USDA, 1972). Figure 3 presents a vegetation map of the basin based on US Forest Service aerial reconnaisance. Trees and plant associations found at several sites around the lake by Thatcher (1976) are presented in Table III.

Franklin and Dryness (1973) mention a particular 
TABLE I

MORPHOLOGY AND CHEMISTRY OF BULL RUN LAKE ${ }^{1}$

\begin{tabular}{|c|c|c|c|}
\hline Parameter & Value & Parameter & Value \\
\hline Elevation & $969 \mathrm{~m}$ & Conductivity & 15.6 umhos $/ \mathrm{cm}$ \\
\hline Maximum depth & $85 \mathrm{~m}$ & $\mathrm{pH}$ & 7.1 \\
\hline Vol ume & $0.037 \mathrm{~km}^{3}$ & Turbidity & 0.24 NTU \\
\hline Mean depth & $20 \mathrm{~m}$ & $\mathrm{NO}_{3}-\mathrm{N}$ & $0.02 \mathrm{mg} / \mathrm{L}$ \\
\hline Surface area & $1.8 \mathrm{~km}^{2}$ & $\mathrm{NH}_{3}-\mathrm{N}$ & $<0.02 \mathrm{mg} / \mathrm{L}$ \\
\hline \multirow[t]{4}{*}{ Drainage area } & $8.94 \mathrm{~km}^{2}$ & $P 0_{4}-P$ & $<0.003 \mathrm{mg} / \mathrm{L}$ \\
\hline & & $\mathrm{Si}$ & $1.47 \mathrm{mg} / \mathrm{L}$ \\
\hline & & Alkalinity & $0.16 \mathrm{milleq} / \mathrm{L}$ \\
\hline & & Secchi disc depth & $11.5 \mathrm{~m}$ \\
\hline
\end{tabular}




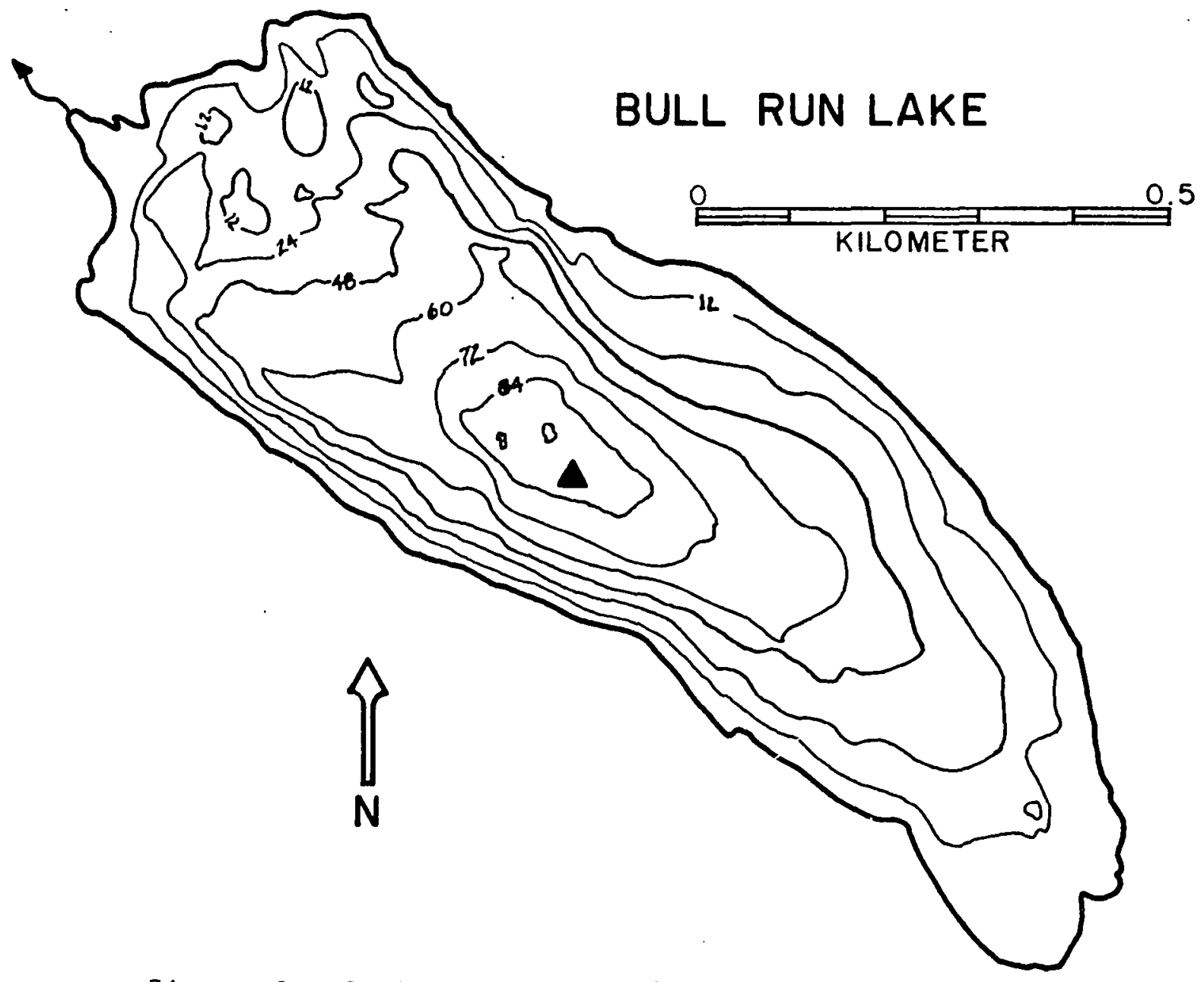

Figure 2. Bathymetric map of Bull Run Lake.

Countour interval is $12 \mathrm{~m}$. Solid triangle marks 
TABLE II

BULL RUN PHYTOPLANKTON 1

Species

Cyclotella stelligera

Melosira distans

Nitzschia paleacea

Cyclotella ocellata

Achnanthes minutissima

Chroococcus prescottii

Navicula sp.

Melosira ambigua

Stephanodiscus astrea var. minutula

Eunotia elegans

Cymbella lunata

Cocconeis placentula var. euglypta

Eunotia $s p$.

Total count $=94 \mathrm{cell} / \mathrm{s} / \mathrm{mL}$

1. Sample taken at $0.5 \mathrm{~m}$ on $7 / 29 / 80$.
Percent

80.3

6.8

1.5

1.5

1.5

1.5

1.5

0.8

0.8

0.8

0.8

0.8

0.8 


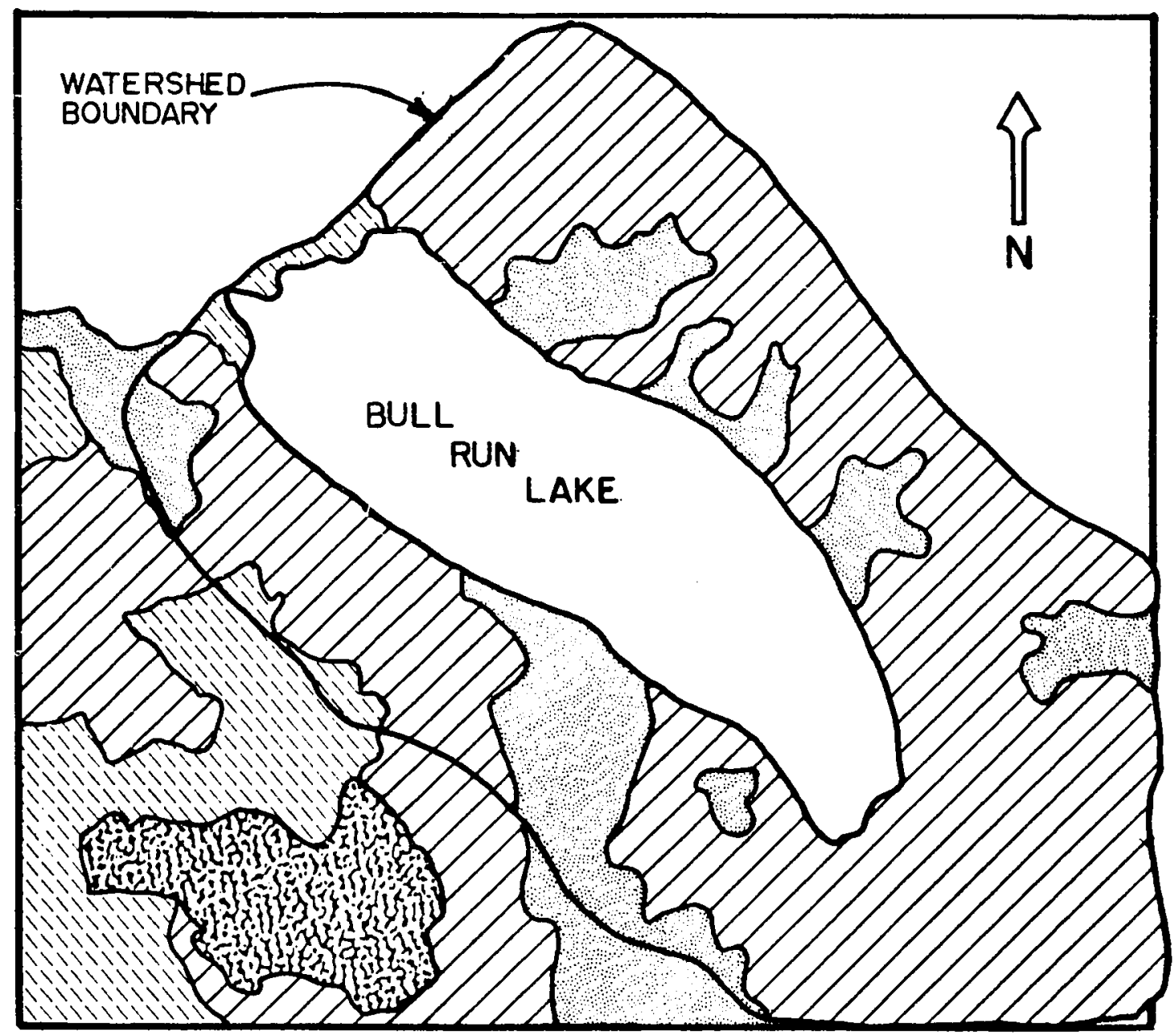

$7721 "$ dbh, 70-100\% canopy closure, old growth silver fir, Douglas-fir.

Non-commercial trees or rocky.

spis > 21" dbh, 70-100\% canopy closure, old growth 5.5 silver fir, western hemlock and noble fir.

11-21" dbh, 70-100\% canopy closure, silver fir Douglas-fir, western hemlock.

Figure 3. Vegetation map of area surrounding Bull Run Lake, based on U.S. Forest Service aerial reconnaisance. 
TABLE III

VEGETATION IN THE BULL RUN LAKE BASIN ${ }^{1}$

Plant Assoctations

Abies amabilis/oplopanax horridum

Abies amabilis/streptopus roseus

Abies amabilis/Vaccinium alaskense

Abies amabilis/xerophyllum tenax

Sedum divergens/Solidago SPP. (Dry meadow)

Acer circinatum/Cryptoramma crispa/Alnus sinuata (Talus community)

$$
\text { Canopy Trees }
$$

Abies amabilis

Pseudotsuga menziesii

Abies procera

Thuja plicata

Tsuga heterophylla

Small Trees and Seedings

Abies amabilis

Pseudotsuga menziesij

Acer circinatum

Tsuga heterophylla

Alnus sinuata

Shrubs

Gaultheria shallon

Menziesia ferruginea

Oplopanaz horridum

Pachystima myrsinites

Rubus macrophyllum
Rubus parvifiorus

Rubus spectabilis

Vaccinium alaskense

Vaccinium membranaceum

vaccinium parvifolium

1. Data from Thatcher (1976). 
community found in the Abies amabilis zone. On sites subject to deep winter snow and extensive snow creep, Alnus sinuata, a shrubby alder, can form stable communities. The Bull Run Lake basin has sites with conditions well suited to the development of this community.

There has been no logging or recreational activity near the Bull Run Lake, and very little disturbance in the basin. There have been several changes at the lake resulting from its inclusion in the Portland water system (Raymond, 1980). In 1914 a sluice gate was built at the outlet to deepen the lake. At this time seepage holes, described by witnesses as whirlpools (Willis, personal communication), were noticed in the lake. A dike was built to separate most of them from the main lake. The remainder were filled with earth between 1917 and 1920. In 1957 the old dam was replaced with a new concrete structure and the lake surface raised an additional $2 \mathrm{~m}$. At this time the old sluice gate, which had been abandoned in 1929 was rebuilt. In 1958 a jeep trail was built to the lakeshore, permitting vehicle access for the first time. This remains the only road to the lake. In 1961 the outlet from the lake at the dam was deepened in an attempt to increase useable storage at the lake. In 1980 Bull Run Lake received a light 
dusting of volcanic ash from Mt. St. Helens.

Because of its depth, protection from wind action by surrounding ridges, small drainage area, and freedom from disturbance, Bull Run Lake is an ideal candidate for preserving the record of natural fluctuations in past conditions. 


\section{METHODS}

\section{Collection and Pretreatment}

Cores were collected from Bull Run Lake on three occasions during the summer of 1979. Three types of sampler were used; an open barrel gravity corer with a check valve to ensure core retention, a modified Kullenberg type piston corer designed and built at Portland State University, and a latex powered light-weight piston corer described by Murray (1976). The gravity corer and the light weight piston corer were capable of collecting cores up to $1.5 \mathrm{~m}$ long, and the modified Kullenberg corer was capable of collecting up to a $4.5 \mathrm{~m}$ core. All three corers collected the sediment in $5 \mathrm{~cm}$ diameter thin wall polycarbonate tubes.

Twenty-seven cores were collected from various parts of the lake. All of the cores analyzed for this study were from the deepest area (Figure 2). The cores ranged in length from $0.5 \mathrm{~m}$ to $3.5 \mathrm{~m}$. Most of the cores were taken with the light weight piston corer and were about $1 \mathrm{~m}$ long. Working from a small baat necessitated by the difficult access, and retrieving the samples by hand from $80 \mathrm{~m}$ depth limited the use of 
the heavier and longer corers.

On each sampling occasion one representative core was extruded out of the top of the coring tube in the field, cut into $1 \mathrm{~cm}$ slices which were placed in polyethylene whirl-pack bags and placed in an ice chest for transport to the Iaboratory. The remaining cores were transported back to the laboratory in the tubes while kept upright. All cores were stored in their sample tubes at $4^{\circ} \mathrm{C}$ in the dark until further analysis. X-radiographs were taken of all cores still in their tubes before they were extruded for further analysis. These radiographs revealed stratigraphic details otherwise concealed in the uniform appearing sediment, and allowed the correlation of depth with age in the different length cores. The radiographs also revealed several cores which were incomplete, or in which the corer had i.enetrated the sediment at an oblique angle.

Cores were extruded in the laboratory onto polyethylene sheet held in semicircular channels after the overlying water had been removed by careful suction. Cores were cut into $1 \mathrm{~cm}$ thick slices and the location of the slices was marked on prints of the radiographs. The very loose sediments at the top of the core were removed by spooning and careful extrusion before the core was extruded into the channel. 
One of the longer cores was used for carbon-14 dating. Sections that included stratigraphic markers visible on the $x$-radiographs were cut from the core. Each section for dating was $10 \mathrm{~cm}$ long. Carbon 14 dates were provided by Geochron Laboratories of Cambridge, MA, and by the Department of Chemistry of the University of Washington in Seattle.

Pollen and Diatoms

Subsamples for diatom and pollen analysis were taken with a stainless steel mini piston corer $0.4 \mathrm{~cm}$ in diameter. Each core to be sampled was sub-cored at $1 \mathrm{~cm}$ intervals before being sliced. The subcores were extruded, $0.5 \mathrm{~cm}$ was cut off of each end and the remainder was dried in a covered container at $105^{\circ} \mathrm{C}$ and weighed to the nearest $0.1 \mathrm{mg}$.

Pollen samples were prepared for mounting by a modification of the methods given in Moore and Webb (1978 p. 23). Weighed dry samples were boiled for 20 minutes with $10 \%(w / v) \mathrm{KOH}$, washed by centrifugation and rinsing, boiled for 10 minutes with concentrated $H F$, washed again, and boiled for 2 minutes in $10 \%(v / v)$ $\mathrm{HCl}$. After the final wash, 1 drop of $10 \% \mathrm{KOH}, 4$ drops of aqueous safranine and $4 \mathrm{~mL}$ of water were added to stain the pollen. The prepared pollen was then mounted on slides for examination. Pollen slides were also 
used for enumeration of charcoal grains and planktonic invertebrates.

Diatom samples were prepared for mounting by a modification of the method given in Collins and Kalinsky (1977 p.4). A weighed sample of dried sediment was placed in a $100 \mathrm{~mL}$ beaker with $5 \mathrm{~mL}$ of filtered distilled water and $5 \mathrm{~mL}$ of $50 \% \mathrm{H}_{2}{ }^{0} 2^{\circ}$ After 30 minutes, 5 drops of $10 \% \mathrm{~K}_{2} \mathrm{Cr}_{2}{ }^{0} 7$ was added. The beaker was allowed to stand until the violent oxidative reaction and color change from deep purple to pale yellow was complete and all bubbling had stopped. The samples were then transferred quantitatively to centrifuge tubes for repeated washing until all trace of the yellow color was gone. The prepared diatoms were mounted on microscope slides for examination. After treatment, both diatoms and pollen were prepared for observation in the same way. This method is a modification of McNabb's $(1960)$, and is based on the inverted microscope method of counting phytoplankton (Lund, et al., 1958). It provides a rapid way to obtain a quantitative count with well defined statistical properties (Legendre and Watt, $1972)$

After final washing, each sample was quantitatively transferred from the centrifuge tube to a volumetric flask and diluted to the mark, usually 
$1000 \mathrm{~mL}$. A known volume, from 5 to $25 \mathrm{~mL}$ depending on the original sample weight, was pipetted from the well-mixed suspension using a wide bore pipet. This aliquot was added to a membrane filter apparatus containing $50 \mathrm{~mL}$ of filtered, distilled-deionized water. The suspension was gently filtered to dryness leaving a random distribution of particles on the surface of the membrane.

Immediately after filtering, two squares, $1 \mathrm{~cm}$ on a side, were cut from the filter. Each was placed on top of a drop of silicone immersion oil on a microscope slide. The slide, with two replicate sections of membrane filter, was placed in a loosely covered container in a glove box to permit the filter to dry and become clear. When the filter was clear, a second drop of immersion oil was added on top of the filter, a cover slip was added, and the slide was sealed with a specially formulated sealant (Sally's Hard-as-Nails nail polish; pink for pollen, clear for diatoms to allow for easy identification of slide type from a distance).

slides were counted using phase contrast microscopy at $400 x$ for pollen and $1000 x$ for diatoms by the random field method (McNabb, 1960; Legendre and Watt, 1972). Thirty or 60 fields were scored for presence or absence of each taxon. The number of each 
taxon per gram of sediment was calculated by

$$
n=-(\ln (1-f / F))(S / M)(V / G)(1 / V)
$$

where

$$
\begin{aligned}
& n=\text { number of cells or grains per gram dry wt. } \\
& f=\text { number of fields with the taxon present } \\
& F=\text { the total number of fields viewed } \\
& S=\text { the area of the filter } \\
& M=\text { the area of the microscope field } \\
& V=\text { the final dilution volume of the sample } \\
& G=\text { the weight of sediment treated } \\
& V=\text { the volume of sample filtered. }
\end{aligned}
$$

slides were counted in random sequence to reduce the effect of spurious trends resulting from changes in identification.

Pollen grains were identified using Moore and Webb (1978), McAndrews et al. (1973), Kapp (1969), Faegri and Iverson (1975), and reference slides from the Quaternary Research Center at the Universfty of Washington, Seattle. Because of the difficulty in identification of Cuppressaceae pollen, only grains with gemmae clearly present were counted. It is possible that Larfx pollen was present in the samples, but I was not able to separate it from pseudotsuga, and Larix was not included in the pollen diagrams. Alder pollen was present in the slides in two distinct forms. One form had clear and obvious sulci and was assigned 
to Alnus rubra, while the other had very faint sulci and was assigned to Alnus sinuata (Nickman, personal communication). Nomenclature for plants follows that of Hitchcock and Cronquist (1973).

Diatoms were identified according to Patrick and Reimer (1966, 1975) and Hustedt (1930, 1942). Nomenclature follows Patrick and Reimer and Collins and Kalinsky (1977). Cyclotella stelligera was present in the samples in two forms. These were counted separately, but have been combined in the diatom profiles.

\section{Physical and Chemical Methods}

Water content of the sediment was measured by weighing subsamples taken at $1 \mathrm{~cm}$ intervals before and after drying for 24 hours at $105^{\circ}$ C. An approximation of organic carbon content was obtained by measuring weight loss of dried samples after ignition at $600^{\circ} \mathrm{C}$ for one hour. To check the validity of the results of

the loss on ignttion ( $L O I), 5$ samples from different depths in the core were analyzed for total carbon with a carbon analyzer at the Oregon Department of Environmental Quality laboratories.

Sediment density was measured by displacement. A small diameter $10 \mathrm{~mL}$ graduated cylinder containing 5.0 $\mathrm{mL}$ of filtered deionized water was weighed. A volume of sediment was introduced to the cylinder using the 
stainless steel minicorer. The change in volume and weight was used to calculate the density of the sediment in $\mathrm{g} / \mathrm{cm}^{3}$.

The preparation of sediment for chemical analysis followed the methods of Bortleson (1970). To extract acid soluble phosphorus from the sediment samples, 20 $\mathrm{mL}$ of $1 \mathrm{~N}$ strong acid extractant $(0.75 \mathrm{~N} \mathrm{HCl}$ and $0.25 \mathrm{~N}$ $\mathrm{H}_{2} \mathrm{SO}_{4}$ ) was added to $0.2 \mathrm{~g}$ sediment in a $50 \mathrm{~mL}$ erlenmyer flask. The mixture was shaken on a rotary shaker for 20 minutes, filtered through a prewashed 0.45 um pore membrane filter, and diluted to $50 \mathrm{~mL}$. This extract was anlyzed for phosphorus by the vanadomolybdate yellow procedure (APHA, 1979). Results were recorded as moles phosphorus per gram dry weight of sediment. Samples analyzed for trace elements by atomic absorption spectrophotometry (AAS) were digested by a procedure modified from Bortleson (1970). Sediment samples ( $0.5 \mathrm{~g}$ dry weight) were placed in $100 \mathrm{~mL}$ polypropylene beakers with $10 \mathrm{~mL}$ of $50 \% \mathrm{H}_{2} \mathrm{O}_{2}$ and heated in a sand bath at approximately $100^{\circ} \mathrm{C}$ until dry. Ten $\mathrm{mL}$ of $48 \% \mathrm{HF}$ were added to the beakers and they were again heated until dry. The residue was transferred quantitatively to $100 \mathrm{~mL}$ kjeldahi digestion flasks using $10 \mathrm{~mL}$ of a solution consisting of $60 \% \mathrm{HClO}_{4}$ and concentrated $\mathrm{HNO}_{3}$ (3:5 by volume). This mixture was heated in a digestion apparatus until perchlorate fumes 
appeared. The digests were then transferred to $100 \mathrm{~mL}$ volumetric flasks, diluted to volume, transferred to linear polyethylene bottles and stored until analysis. Replicate samples, blanks and standards were prepared in the same manner.

Samples were analyzed using an Instrumentation Laboratories Model 550 atomic absorption spectrophotometer with dual beam and background correction.

To measure other trace constituents, samples were analyzed by instrumental neutron activation analysis (INAA) using standard methods (Wainerdi and Uken, 1971; Laul, 1979). Weighed samples in new polyethylene vials were irradiated for one hour in a nuclear reactor, allowed to decay for 5 days and then counted on a Tracor Northern model TN 4000 gamma ray spectrometer. Counting time was 1000 seconds for samples and 2000 seconds for standards. Standards used for comparison were USGS standard W-1 (Flanagan, 1976) and RHO-SA-93 (Additon and Seil, 1979). Gamma ray energy peaks for each nuclide were obtained from Gordon et al.(1968). In addition to these analyses, several samples from identifiable levels in the cores were sent to Georgia Institute of Technology for analysis of crystal structure by $x$-ray diffraction.

Particle size distribution of sediment samples 
were obtained by analysis on a Coulter Model Zbi particle counter equipped with a C-1000 Channelizer. Wet sediment was washed through a No. 200 mesh soil screen (opening size $75 \mathrm{um}$ ). The material passing through the screen was diluted to obtain an appropriate particle concentration for counting, and run on the Coulter counter using a 70 um diameter aperature tube. Data were collected directly from the counter, analyzed and plotted on a Tektronics 4051 graphics computing system. 
RESULTS

Description of the cores

When extruded from the sampling tubes, the sediment appeared to be a uniform dark, green-tinted brown gyttja. In some cores two layers of a more clay-like consistency and tan color were noted. At the bottom of two cores there was a firm, almost rubbery, grey layer approximately $1.5 \mathrm{~cm}$ thick. When dry, the sediment became a light tan color and more structure was evident in the cores. The two clay-like layers noted in the wet sediment were especially noticeable because they shrank much less on drying than the rest of the core. In addition, there were concentrations of fibrous, apparently organic, material associated with these layers. In the layer nearest the surface of the sediment were recognizable plant remains including leaf fragments, needles and seeds. At two locations the dry cores separated spontaneously at layers of coarse, sandy material. other areas in the cores were notable for increased concentration of charcoal granules, or of unidentified mineral grains. 
The grey layer at the bottom of two cores dried to a very white fine glassy powder which was identified as Mt. Mazama ash by microscopic characteristics (Beeson, personal communication) and elemental composition (Table IV).

\section{Correlation and Chronology}

The $x$-radiographs with the best resolution revealed a complex pattern of stratigraphic structure in the cores. Twenty-five separate layers were identified in one $70 \mathrm{~cm}$ long core. Not all of the radiographs showed sufficient resolution to identify all these layers, but seven layers were present and identifiable in all the complete cores. These layers provided the basis for determining the completeness of different cores and for detecting problems in sampling such as oblique entry of the corer into the sediment. The seven $x$-ray dense layers were identified by letters $A$ through $G$ in sequence from the layer nearest the surface of the sediment (Figure 4). Comparison of the radiographs with data on the physical appearance of the extruded cores indicates that the areas of banding on the radiographs correspond to layers of anomalous structure in the core. The stratigraphy of the cores is summarized in Table $V$. Based on the $x$-radiographs, samples were taken 
TABLE IV

\section{CONCENTRATION OF SELECTED ELEMENTS IN VOLCANIC ASH SAMPLES FROM SOME CASCADE \\ RANGE VOLCANOES}

\section{Concentration (ppm except where noted) ${ }^{1}$}

\begin{tabular}{|c|c|c|c|c|}
\hline Element & Bull Run Lake & Mt. Mazama & Newberry Crater & Mt. St. Helens \\
\hline La & 18.8 & $16.5-22.1$ & $25.6-29.7$ & $11.5-12.7$ \\
\hline $\mathrm{Ce}$ & 38.0 & $40.9-52.1$ & $56.0-67.6$ & $30.4-34.8$ \\
\hline $\mathrm{Sm}$ & 3.8 & $3.2-6.4$ & $4.8-7.1$ & $2.5-3.3$ \\
\hline Eu & 0.66 & $0.58-1.06$ & $0.70-0.98$ & $0.83-0.89$ \\
\hline Yb & 1.82 & $1.59-2.62$ & $3.45-4.6$ & $0.80-1.00$ \\
\hline Lu & 0.33 & $0.25-0.74$ & $0.64-0.94$ & $0.12-0.24$ \\
\hline Th & 4.33 & $4.14-5.96$ & $10.94-13.6$ & $2.57-2.97$ \\
\hline Hf & 4.9 & $5.00-7.10$ & $7.09-8.8$ & $3.54-3.98$ \\
\hline Co & 2.7 & $2.54-5.25$ & $0.71-1.84$ & $7.48-8.12$ \\
\hline $\mathrm{Fe}(x)$ & 1.6 & $0.87-2.13$ & $1.22-1.47$ & $2.68-2.84$ \\
\hline Sc & 5.77 & $4.87-6.93$ & $4.37-5.69$ & $5.49-5.85$ \\
\hline $\mathrm{Cr}$ & $n \cdot d .2$ & $?-6.8$ & -3.2 & $5.3-8.5$ \\
\hline
\end{tabular}

1. Data from Randle, et al. (1971).

2. n.d. = not detected 


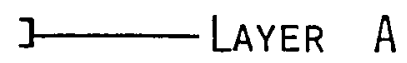

$\sim$ J LAYER B
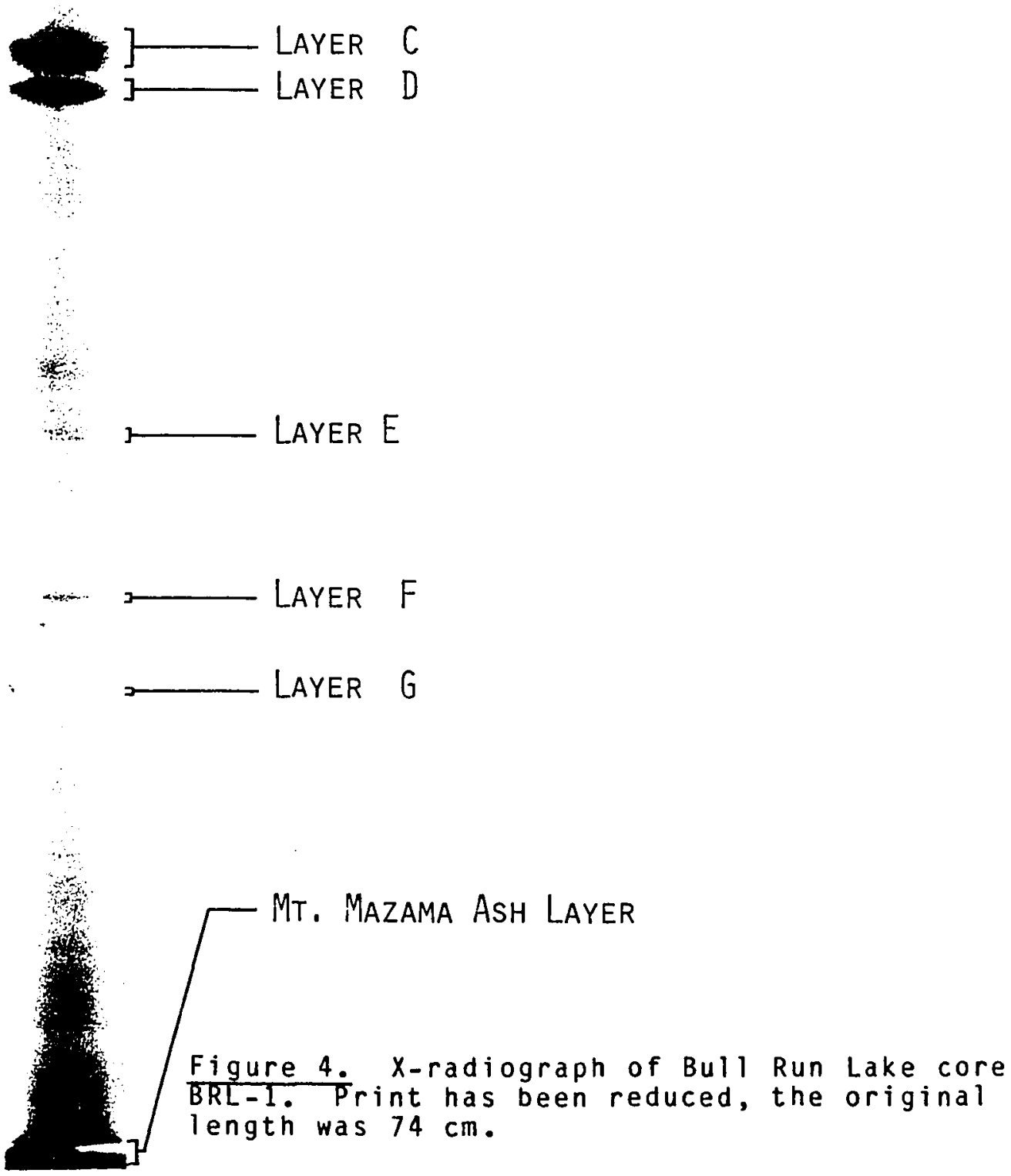
TABLE $V$

\section{STRATIGRAPHY OF BULL RUN LAKE SED IMENT CORES}

\begin{tabular}{|c|c|c|}
\hline Layer & $\mathrm{Age}^{1}$ & X-Ray Appearance \\
\hline A & 50 & $\begin{array}{l}\text { Diffuse band, slightly darker } \\
\text { than rest of core, no dis- } \\
\text { tinctly different texture }\end{array}$ \\
\hline B & 300 & Narrow, dense, dark layer \\
\hline$c$ & 1300 & $\begin{array}{l}\text { Thick, dark band, has a } \\
\text { fibrous appearance and } \\
\text { shows internal layering }\end{array}$ \\
\hline D & 1450 & $\begin{array}{l}\text { Thick dark band composed of } \\
\text { a thin, very dark band lying } \\
\text { just above a thicker. more } \\
\text { fibrous band }\end{array}$ \\
\hline E & 2350 & $\begin{array}{l}\text { Diffuse band, slightly } \\
\text { darker than rest of core }\end{array}$ \\
\hline $\mathbf{F}$ & 3300 & $\begin{array}{l}\text { Narrow dark band, no } \\
\text { distinct texture }\end{array}$ \\
\hline G & 3620 & $\begin{array}{l}\text { Narrow oand of clearly } \\
\text { distinct granules }\end{array}$ \\
\hline
\end{tabular}

1. Age in years b.p. based on carbon-14 dates of core BRL-19. 
from the longest complete core for dating by carbon-14 analysis. Three of the five samples dated contained layers identified on the radiographs. The results of carbon dating are presented in Table VI and Figure 5.

Except for one, the dates all fall on a straight line. The one anomalous date is apparently the result of incomplete penetration of the core tube followed by tipping. As the corer tipped, material from shallower depths in the sediment apparently was drawn into the tube by the suction of the piston.

The validity of the dates obtained is strengthened by the presence of Mt. Mazama ash at the bottom of two cores. The dated core did not penetrate as deep as the Mt. Mazama ash, which has been dated at approximately 6700 years before the present (b.p.)(Fryxe11, 1965).

Calculation of sedimentation rate from the carbon 14 dates indicates a rate of sedimentation in Bull Run Lake of approximately $0.3 \mathrm{~mm} / y e a r$. This is similar to the rate found in Castle Lake, California (Kimmel, 1978), and in Mowich Lake, Washington (Larson, et al., 1976), both lakes of similar characteristics. Performing the same calculation, based on the depth of the Mt. Mazama ash, for the cores containing the Mt. Mazama ash, using a date for the ash of 6700 b.p., gives a sedimentation rate for these cores of 0.08 
TABLE VI

CARBON-14 DATES OF BULL RUN LAKE CORE BRL-19

\begin{tabular}{|c|c|c|c|}
\hline Sample Depth (cm) & $X$-Ray layer & C-14 Age (Lab No.) & Calendar Date ${ }^{1}$ \\
\hline $5-14$ & $A$ & Modern (UW-663) & $\begin{array}{ll}1675-1710 & A D \\
1805-1930 & A D\end{array}$ \\
\hline $43-48$ & $C / D$ & $1360 \pm 165(G X-7302)$ & $420-900 \mathrm{AD}$ \\
\hline $91-97$ & $\mathrm{~F}$ & $3320 \pm 85(U W-662)$ & $1880-1410 B C$ \\
\hline $154-159$ & - & $5700 \pm 100(U W-661)$ & $4885-4495 B C$ \\
\hline $300-305$ & - & $5460 \pm 60(U W-660)$ & $4430-3995 B C$ \\
\hline
\end{tabular}

1. Calendar dates based on Klein et al. (1982). 


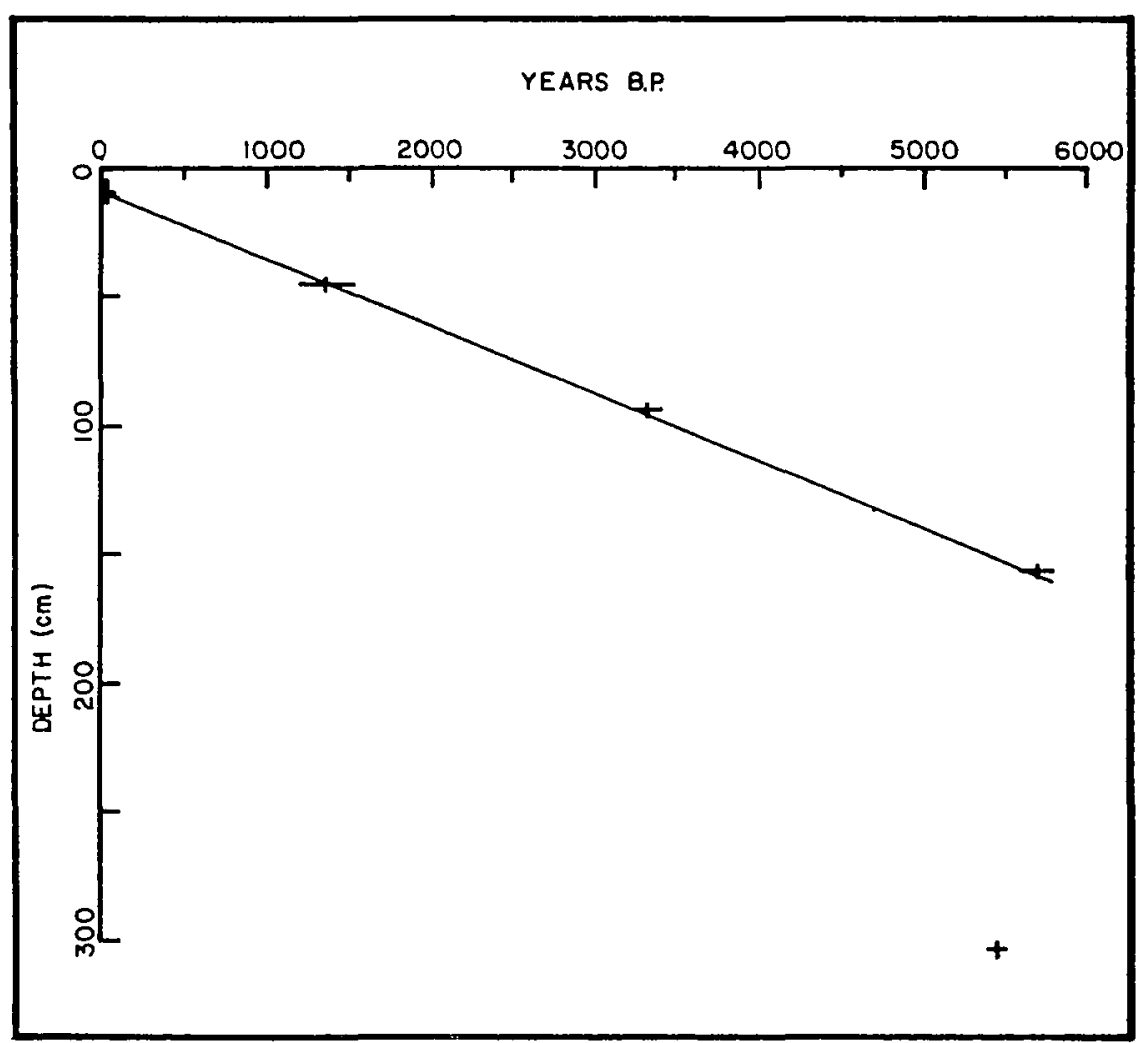

Figure 5. Carbon-14 age versus depth in sediment for Bull Run Lake core BRL-19. 
$\mathrm{mm} /$ year, only $26 \%$ of the rate in a different core taken from the same part of the lake. Examination of the $x$-radiographs indicated that both cores were complete, exhibiting all seven named layers. The discrepancy can be attributed to compression of the cores containing the Mt. Mazama ash. These cores were taken by gravity corer. Similar compression by gravity corers has been noted in other work (Hongve and Erlandsen, 1979; Baxter et a1., 1981).

Using the data from the carbon-14 dates and the $x$-radiographs, it was possible to correlate the cores and to assign each level of each core to a particular age class. For each core analyzed, the depth of a particular layer and the date measured for that layer were used to fit a straight line using linear regression. Using the linear relationship, dates were calculated by interpolation for all the undated, named layers. Calculated dates for the named layers in all cores were averaged to obtain a mean age b. p. of all layers in the cores. These mean ages were used to compare parameters measured in different cores across time, and to account for the different depths resulting from compression of some cores. The results of this analysis are presented in Table VII. 
TABLE VII

CALCULATED AGES FOR VARIOUS FEATURES IN BULL RUN LAKE CORES

\section{Depth in Core $(\mathrm{cm})$} Core

Layer $\mathrm{C}-14$ Age

A 20

B -.

C $\quad 1360$

D 1360

E -

F 3320

G

12

\begin{tabular}{llll}
2 & 7 & 12 & 19 \\
\hline 3 & 10 & $-\ldots$ & 10
\end{tabular}

$520 \quad--\quad 18$

$\begin{array}{llll}17 & 52 & 4 & 45\end{array}$

19

28

28

39

42
Calculated Age (b.p.)

Core

\begin{tabular}{|c|c|c|c|c|}
\hline 2 & 7 & 12 & 19 & Mean Age \\
\hline 7 & 10 & -- & 20 & 14 \\
\hline
\end{tabular}

$374 \quad 332 \quad--356 \quad 353$

$\begin{array}{lllll}1291 & 1313 & 1321 & 1301 & 1308\end{array}$

$\begin{array}{lllll}1475 & 1469 & 1399 & 1498 & 1448\end{array}$

$2393 \quad-2536 \quad-$ - 2465

$3310 \quad--3320 \quad 3292 \quad 3315$

$3586 \quad--3634 \quad--\quad 3610$ 


\section{Physical Characteristics of Sediment}

Figure 6 presents the results of gravimetric analysis of the cores for percent water content and percent LOI. Figure 7 presents the results of density determination of wet sediment. Figure 8 shows the ratio of percent water content to percent loss on ignition. Basic statistics for these parameters are presented in Table VIII.

Percent water content and percent LOI are highly correlated $(P<0.001)$, and both show a negative correlation with the ratio of percent water content to percent. LOI. Water content tends to decrease with increasing depth in the sediment.

Note that for all four of these parameters, the value tends to vary only slightly with the exception of several large excursions which correspond to those portions of the stratigraphic record which showed anomalies on the $x$-radiographs.

Five samples were analyzed for total organic carbon. The results of this analysis are presented in Table IX. These results indicate good correspondence between weight loss on ignition and total organic carbon.

\section{Chemical Characteristics of the Sediment}

The amount of various elements was measured and calculated as concentration per inorganic weight of 


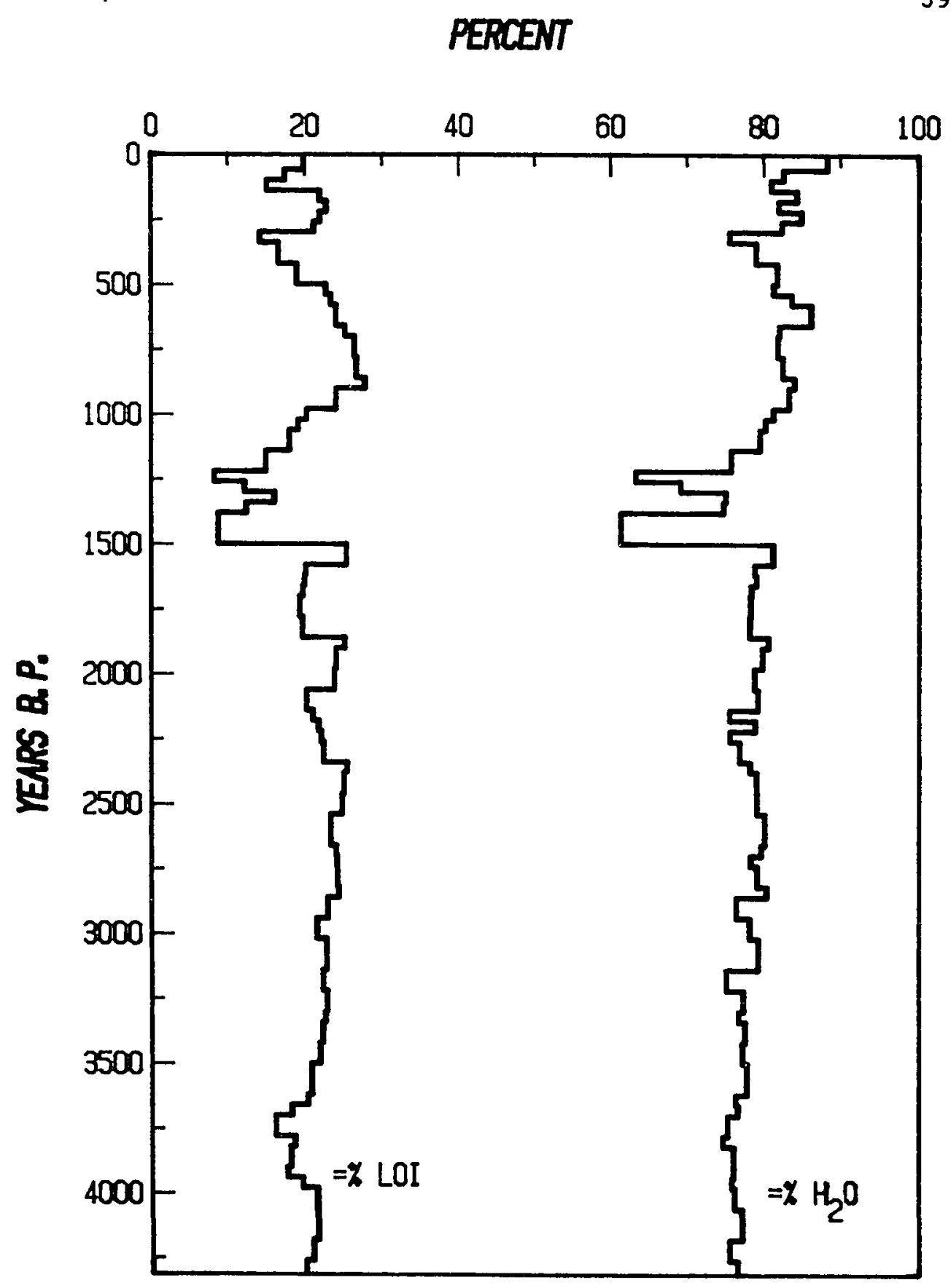

Figure 6. Results of gravimetric analysis of BuाT Run Lake sediment. 


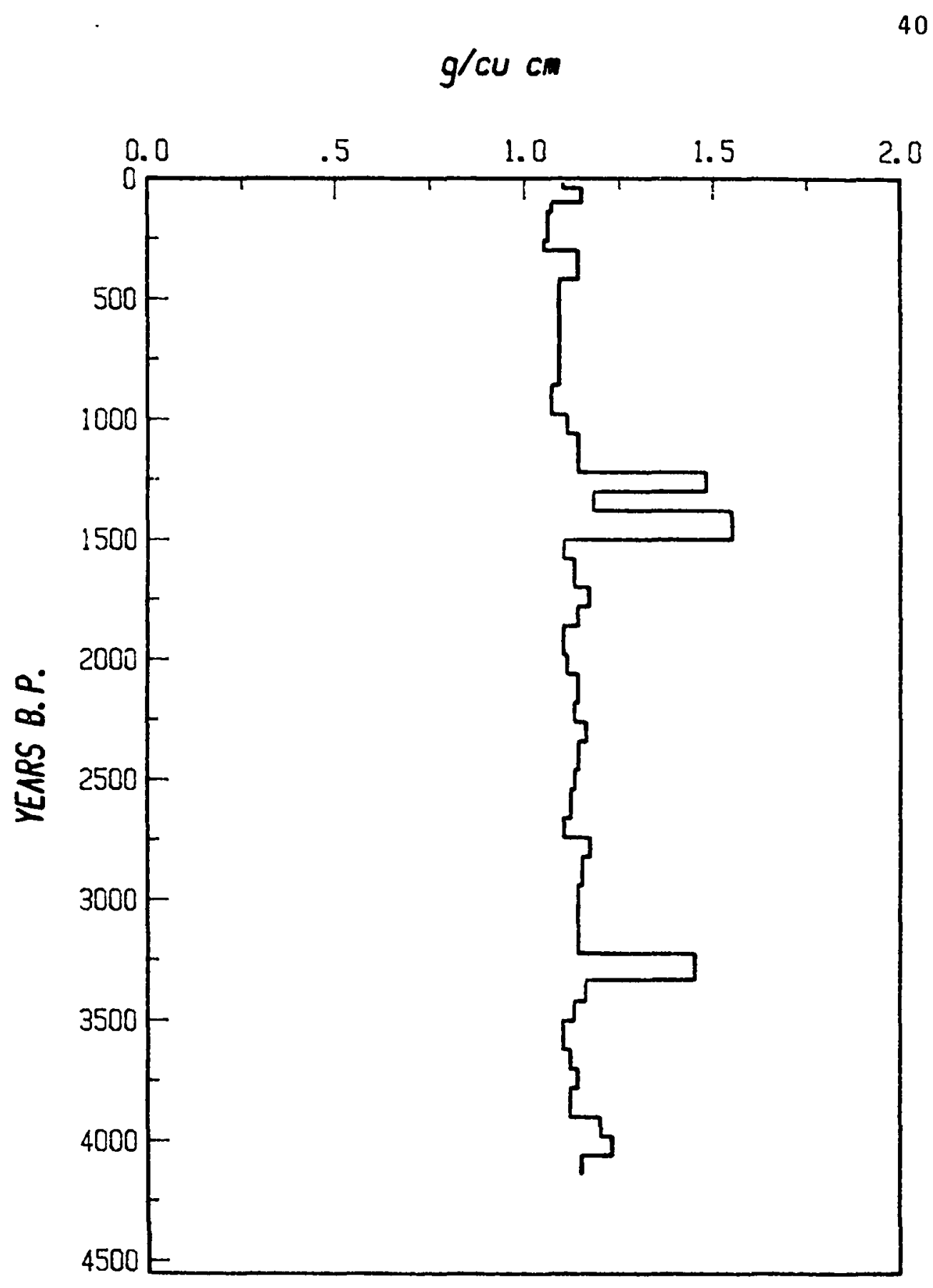

Figure 7. Density of Bull Run Lake sediment. 
$\% \mathrm{H}_{2} \mathrm{O} / \% \mathrm{LOI}$

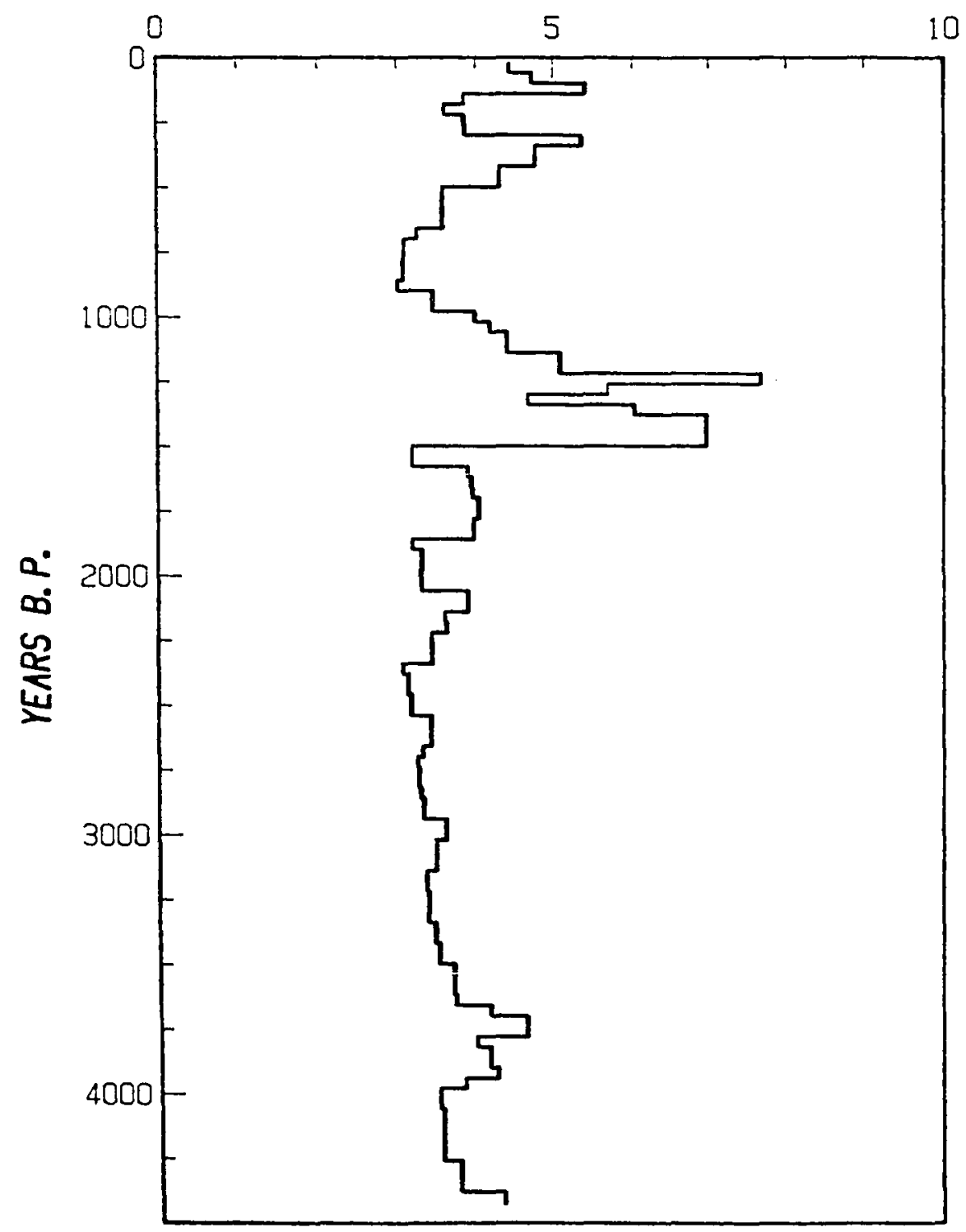

Figure 8. Ratio of water content to loss on ignition (LOI) for Bull Run Lake sediment. 


\section{TABLE VIII}

BASIC STATISTICS FOR GRAVIMETRIC DATA

\begin{tabular}{|c|c|c|c|c|}
\hline & \% Water & Loss on Ignition & Density $\left(\mathrm{g} / \mathrm{cm}^{3}\right)$ & \% Water $/ \%$ LOI \\
\hline Mean & 78.42 & 20.59 & 1.15 & 4.08 \\
\hline Range & 26.95 & 22.95 & 0.50 & 11.33 \\
\hline Std. Dev. & 4.26 & 4.35 & 0.10 & 1.51 \\
\hline Median & 78.53 & 21.67 & 1.125 & 3.62 \\
\hline Maximum & 88.37 & 27.90 & 1.55 & 14.34 \\
\hline Minimum & 61.24 & 4.95 & 1.05 & 3.01 \\
\hline
\end{tabular}


TABLE IX

RESULTS OF CARBON ANALYSIS ON BULL RUN LAKE SEDIMENT

\begin{tabular}{|c|c|c|c|c|}
\hline Sample & \% Water & $\%$ LOI & \% Carbon & \% Carbon $/ \%$ LOI \\
\hline 1 & 75.35 & 21.66 & $\begin{array}{r}9.84 \\
10.26\end{array}$ & $\begin{array}{l}0.45 \\
0.47\end{array}$ \\
\hline 2 & 78.65 & 21.34 & 9.27 & 0.43 \\
\hline 3 & 82.96 & 26.26 & 11.64 & 0.44 \\
\hline 4 & 60.69 & 6.34 & 3.27 & 0.52 \\
\hline \multirow[t]{3}{*}{5} & 77.67 & 14.86 & $\begin{array}{l}8.08 \\
6.09\end{array}$ & $\begin{array}{l}0.54 \\
0.41\end{array}$ \\
\hline & & & & 0.47 \\
\hline & & & Std & 0.05 \\
\hline
\end{tabular}


sediment (taken as that material remaining after ignition at $500^{\circ} \mathrm{C}$ ). The results of this analysis are presented in Figures 9 and 10 .

The general impression of the element data is that of variation about some stable value with periods of perturbation followed by a trend back toward the stable value.

Three elements - cobalt, bromine and phosphorus - appear to differ from the general pattern. Cobalt has a stable mean of $18.3 \mathrm{ppm}$ from the beginning of the record until a peak at about 1950 b.p. Following this peak a new equilibrium is established with mean $12.9 \mathrm{ppm}$. These means differ significantly $(P<0.001)$.

Both bromine and phosphorus show a trend with time rather than a stable value. Phosphorus decreases in concentration steadily from the beginning of the record to the surface with a large broad peak between 1220 and 1000 years b.P. Bromine on the other hand, shows a steady increase in concentration from the beginning of the record until the surface. From 1220 years b.p. until the present, the rate of increase of $\mathrm{Br}$ in the sediments appears to have increased. The results of correlation analysis of the chemical data are presented in Table $x$. Based on the correlations in this table, it is possible to separate 

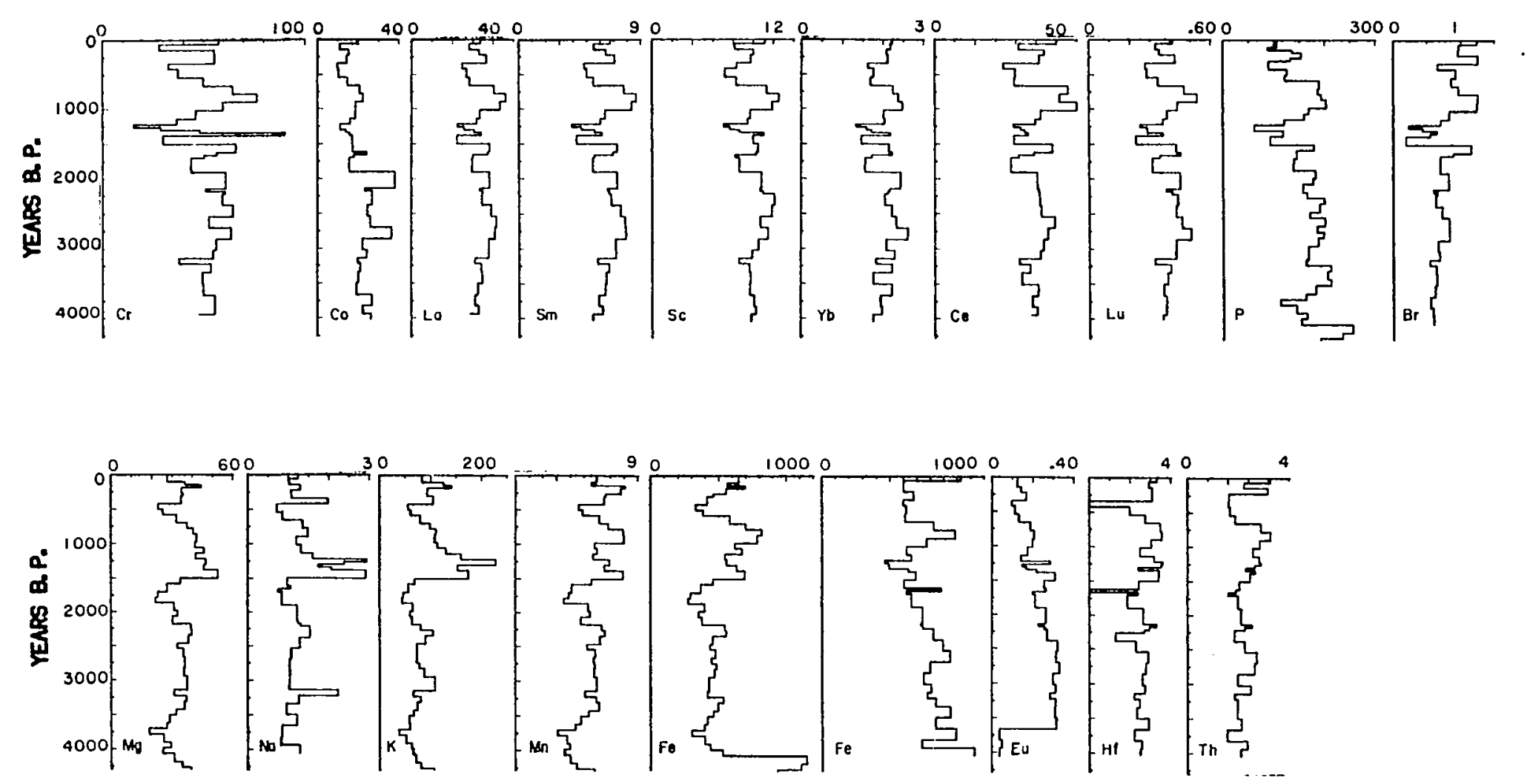

Figure 9. Concentration of elements in Bull Run Lake sediment. Concentration in ppm of ashed weight except $M g, K, M n, F e$, and $P$ in umol/g ash weight, and $\mathrm{Na}$ in $\%$ ashed weight. 


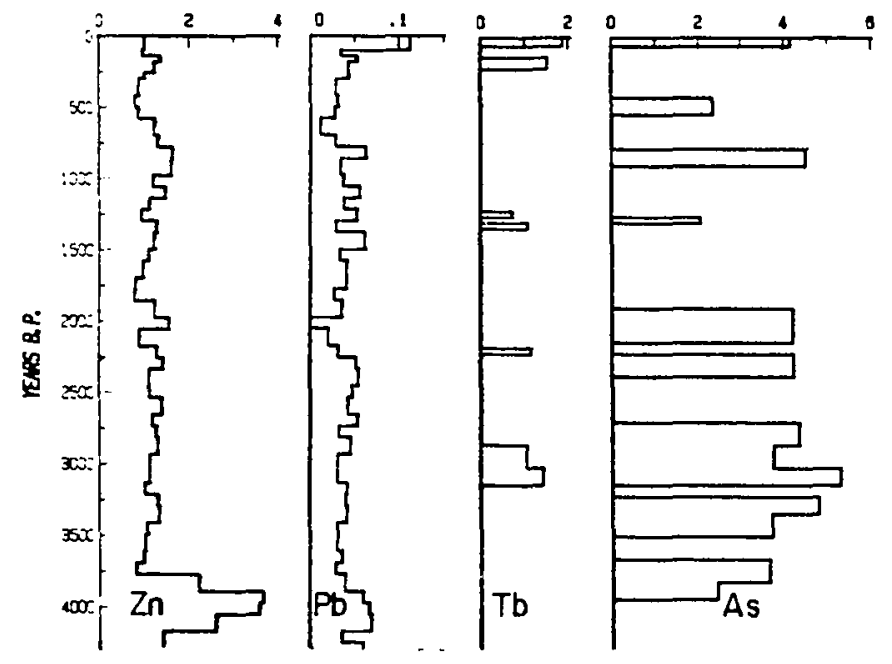

Figure 10. Element concentration in Bull Run Lake sediment. $Z n$ and $P b$ in umol/g ashed weight, Tb and $A s$ in ppm ashed weight. 
TABLE $X$

CORRELATION MATRIX OF ELEMENT DATA FOR BULL RUN LAKE

$w$
0
$\alpha$

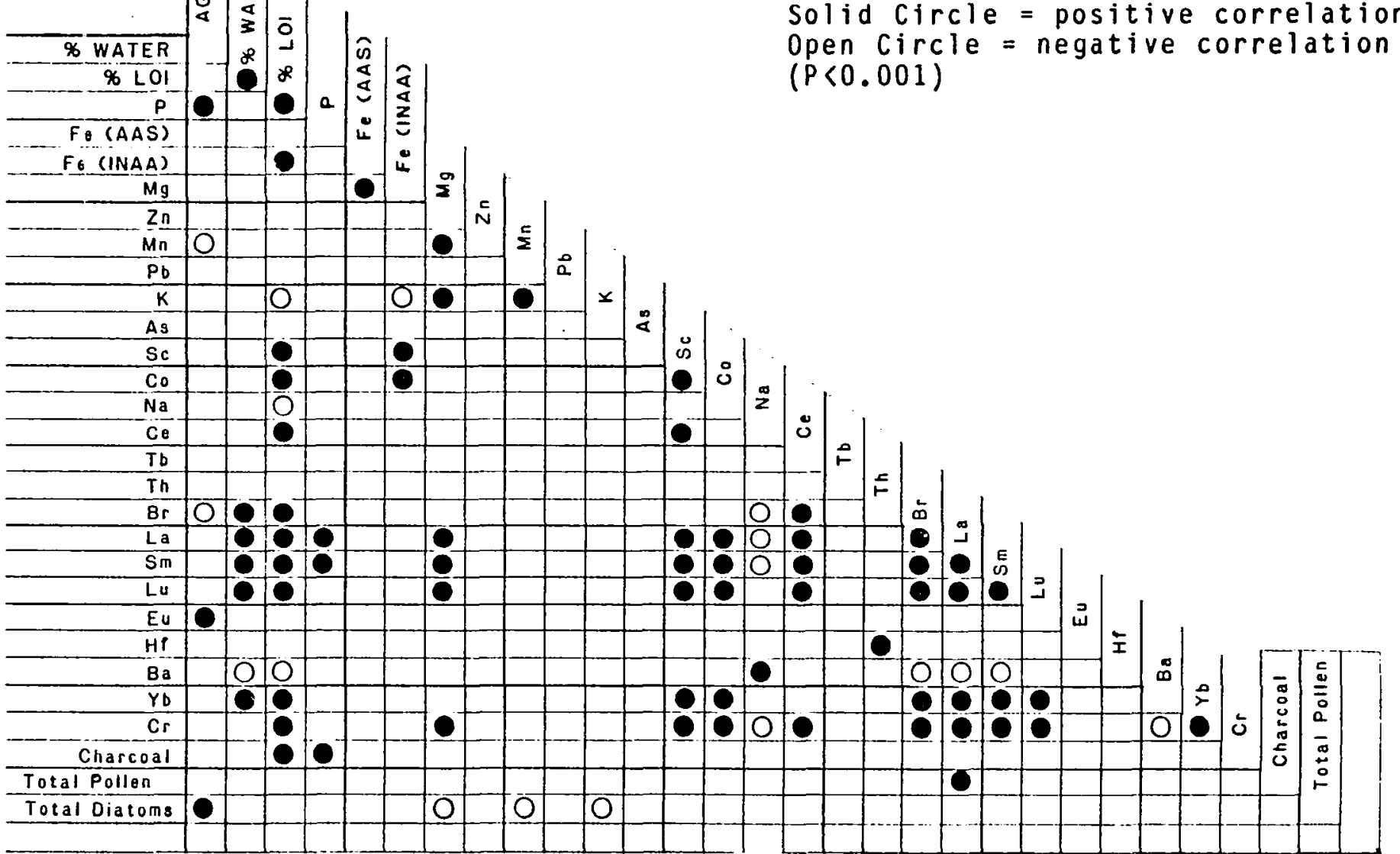


the measured elements into three groups.

Group 1: La, Sm, Sc, Co, Ce, Lu, Yb, Cr, P, Br

Group 2: $\mathrm{Na}, \mathrm{Ba}, \mathrm{K}$, Th, Eu, Hf, Mn, Fe, Mg

Group 3: $\mathrm{Zn}, \mathrm{Pb}, \mathrm{As}$, Tb

Taylor and White (1966) have grouped the elements found in typical andesites based on their ionic radius, charge, and type of bond formation. Comparing the groupings of the Bull Run sediment data to their arrangement, it can be seen that Group 1 is dominated by the rare earth elements, elements with smaller radi $i$, and the smaller radius ferromagnesian elements, Group 2 is dominated by elements with large ionic radius or charge, and Group 3 is composed entirely of elements which form covalent bonds and which tend to form sulfide minerals.

This grouping indicates that elements in Group 1 would be less likely to be differentially affected by sedimentary and weathering processes, while the elements in Group 2, as a result of the difficulty with which they enter a crystal lattice, might be expected to be influenced by weathering processes to a greater extent. The elements in Group 3 are generally found in low abundance in andesites.

The results are similar to the gravimetric data although the elemental data are more variable. There is general variation around some value with major 
excursions at depths which correspond to layers noted on the $x$-radiographs. This general trend holds for both Groups 1 and 2. There is a distinct difference in the response of the two groups. Note that in Group 1 the typical change at 1220 b.p. and 1380 b.p. is a decrease in concentration while in Group 2 the typical change is an increase in concentration.

of the elements in Group 3, only lead and zinc have sufficient data of reliable quality for detailed examination. Both these elements seem to exhibit changes in concentration which are independent of any pattern of layering. Note the large increase in concentration of $z i n c$ in the lower region of the record, and the marked increase in lead in the most recent sediments.

There are some additional aspects of interest in these plots. Phosphorus exhibits a general increase in concentration with increasing age, iron has an increase in the oldest sediments, and europium decreases significantly between 3500 and 4000 years b.p.

In Group 1 most of the elements show a decrease in concentration at layer $A$ with the exception of ytterbium. Most also show an increase at layer B. Exceptions are $\mathrm{Ce}$ and $\mathrm{Co}$ which show no change in trend, and $P$ which shows an increase. There is a broad peak in all concentrations for all elements, except Co, in 
Group 1 beginning with the low at 1250 b.p. and continuing to the low at about 300 b.p. (layer B). It is possible that this is just a return to the normal concentration between the perturbations at those two times.

All elements in Group 1, with the exception of SC and Co, show low values corresponding with layers $C$ and D. Scandium and Co show low concentration at $C$ but do not have a corresponding low value at $D$.

Two other notable changes occur. At about 1750 years b.p., there is a decrease in concentration of all elements in Group 1, and at about 3300 years b.p. (layer $F)$, there is a decrease in concentration in all elements except phosphorus.

The elements in Group 2 show similarities to the elements in Group 1 in that the perturbations in the curves come at similar times in the record. In many cases, however, these flerturbations are of a different sort than in Group 1 . The most striking example is at the time of layer $C$ and $D$, where most of the elements of.Group 2 show an increase, rather than a decrease. All the elements in Group 2 show the increase at both $C$ and $D$ with the exception of iron which shows an increase only at $D$. Sodium, $K$, Mg and Mn all show perturbations at layers $A$ and $B$.

The broad peak of increased concentration between 
1250 and 350 b.p. is not as evident in Group 2. There is a small increase in $\mathrm{Mn}, \mathrm{Fe}, \mathrm{EU}$, Th and $\mathrm{Hf}$, but $\mathrm{Na}, \mathrm{K}$ and Mg exhibit a constant decrease over this interval. From the oldest record to 1500 years ago the element concentrations in Group 2 are stable with a few exceptions. There is a perturbation at 2250 b.p. with $\mathrm{Na}, \mathrm{K}, \mathrm{Mg}, \mathrm{Fe}$ and Mn showing an increase while Th and Hf decrease. At 3300 b.P. Na increases while all the other members of the group decrease. At 3750 b.p. K, $M n$, and Fe decrease and again at 4000 b.p. Mg and $M n$ decrease. Europium is markedly depleted between 3900 b.p. and 3600 b.p.

Iron is the only element for which there are duplicate analyses of the entire record. Samples from different cores were measured by AAS or INAA. These analyses were made on cores with different accumulation rates (or compression), and therefore a different time span for each sample. In addition, the INAA record is composed of analyses of samples from overlapping incomplete cores.

As may be expected, the two records differ in many particulars, but there is an overall similarity, if not in absolute concentrations, then in general trends. Above 1400 b.p. the trends are in quite good agreement, as is the stable concentration value. Below 1400 b.p. correspondence is not as good. The overlap 
of the two cores used for INAA occurs at about 1400 b.P.

of the elements in Group 3, arsenic and terbium values are subject to large relative errors which severely limit any interpretation. These curves are best viewed as indication of presence or absence at concentrations greater than the limits of detection of the method.

Zinc and lead are remarkable for their constancy over time throughout the stratigraphic record. This stability makes the perturbations of these curves more noticeable. Zinc shows a remarkable increase centered on 4000 years b.p. in the vicinity of, but somewhat more recent than increases in iron and phosphorus. Lead shows a nearly threefold increase at the most recent sediments.

There are very few identifiable minerals in the Bull Run sediments. The analysis of the sediment for minerals indicated large amounts of amorphous silica, and low concentration of albite as the major mineral. Some samples had minor amounts of amphibole and quartz. The only clay mineral detected was smectite, often produced from the weathering of volcanic glass.

\section{Pollen Profiles}

The results of pollen analysis are presented as a 
concentration diagram (Colinvaux, 1978) in Figure 11. Table XI lists all palynomorphs identified in the samples counted.

The pollen curves can be contrasted with the trace element curves in that they lack the extreme fluctuations corresponding to the layers noted in the $x$-radiographs. With the exception of layer $B$ there is no consistent response at any of the layers. The most consistent event across the pollen spectrum is a large increase in nearly all pollen species between 1000 and 500 years b.P. This peak corresponds to a similar peak in the abundance of charcoal grains in the sediment.

The total number of species seen in each sample fluctuates, but remains centered on a median value of 17 species for most of the record. At only two periods of time does the curve noticably stray from the median. From about 3000 b.p. to about 2500 b.p. the number of species per sample is low and, after a peak about 950 years b.p., the number of species per sample declines steadily to a low level until about 150 years b.p when it returns suddenly to near the median value. The concentration of pollen grains in the sediment is nearly constant throughout the record, with the exception of the large peak between 1100 years b.p. and $300 \mathrm{~b} . \mathrm{p}$. There is an indication of a small increase in total pollen beginning about 2000 years 


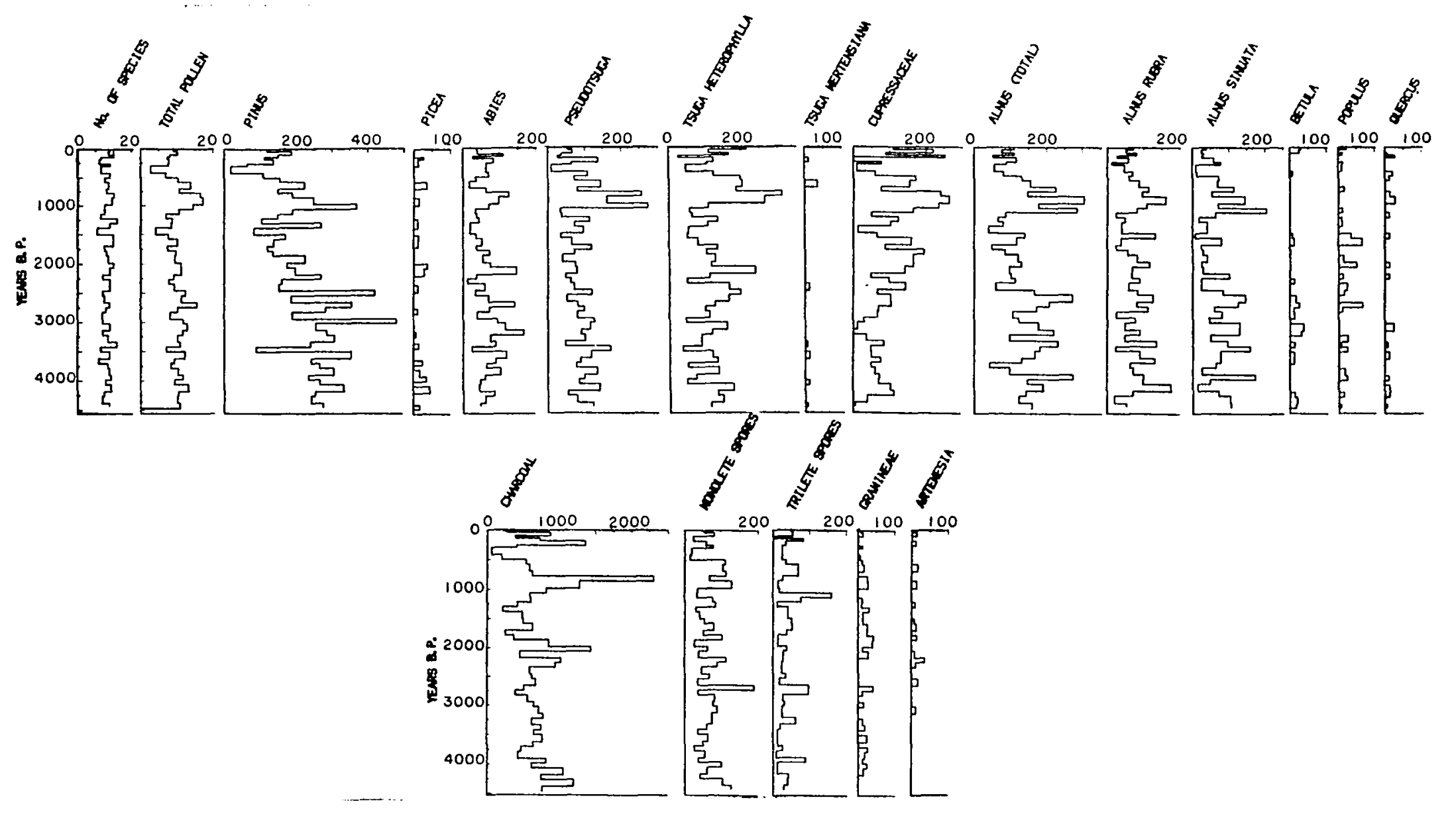

Figure 11. Pollen concentration diaggram from ButI Run Lake. Concentration in $10^{3} \mathrm{grains} / \mathrm{g}$ dry 


\section{TABLE XI}

PLANT TAẌA IDENTIFIED FROM POLLEN IN BULL RUN LAKE SEDIMENT

\begin{tabular}{|c|c|}
\hline 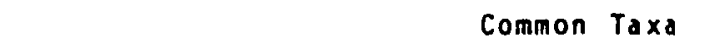 & \\
\hline Monolete spores (Polypodiaceae) & Tsuga heterophylla \\
\hline Trilete spores (Pteridium) & Populus \\
\hline Cupressaceae & Alnus rubra \\
\hline Abies & Alnus sinuata \\
\hline Pinus & Gramineae \\
\hline Pseudotsuga menziesif & \\
\hline Uncommon taxa & \\
\hline Picea & "Castanopsis" \\
\hline Tsuga mertensiana & Corylus \\
\hline Salix & Quercus \\
\hline $\begin{array}{l}\text { Betuloid type } \\
\text { (Betula, Myrica, Corylus) }\end{array}$ & Chenopodium \\
\hline Rare Taxa & \\
\hline Lycopodium & Myrica \\
\hline Taxodiaceae & Fraxinus \\
\hline Myrica & Compositae \\
\hline Urtica & Ambrosia \\
\hline Arceuthobium & Potamageton \\
\hline Sarcobatus & Cyperaceae \\
\hline Nuphar & Sparganum \\
\hline Nymphaea & Typha \\
\hline Ranunculaceae & Smilacina \\
\hline Ribes & \\
\hline
\end{tabular}


b.p. and continuing until 1100 b.p. A sharp decrease in concentration is also noted at layer $D$. The most common pollen in the samples is pinus, usually comprising $15 \%$ to $20 \%$ of the total pollen, and occasionally as much as 40 percent. Pinus shows a steady state from the beginning of the record until about 2500 years ago when a gradual decline begins. A new equilibrium is reached about 1500 years b.p. which persists until the present with the exception of the large peak about 900 b.p. and the low values corresponding to layer $B$. The concentration of pine pollen in the record shows a distinct disruption at the C and D layers.

Western hemlock pollen (Tsuga heterophylla) remains constant throughout almost the entire record. There is a period of low concentration near the C and D layers, and a peak of concentration at about 700 b.p. Samples nearest the surface indicate a recent increase in the concentration of Tsuga pollen.

The pattern of Douglas-fir (Pseudotsuga menziesii) is similar to that of Tsuga heterophylla. When considered in total, alder (Alnus) pollen is more common in the sediment between 4400 and 2500 years b.p. After 2400 years b.p. alder pollen declines to a concentration similar to the present and remains constant until the most recent sediment with the 
exception of a large peak around 800 years b.p.

When pollen counts for Alnus rubra (red alder)

and Alnus sinuata (sitka alder) are considered

separately, a different pattern emerges. Red alder,

though highly variable, maintains a nearly constant

median concentration throughout the record until about

800 years b.p. Since that time there has been a steady

decline in the concentration of red alder pollen in the sediment.

Sitka alder shows a similar pattern, but

demonstrates a definite period of low concentration

beginning about 2200 years b.p. Which continues until

1200 b.p. Following a dramatic increase which peaks

about 1100 b.p., sitka alder has also declined to

numbers near its lowest concentration in the record.

Abies pollen follows a pattern similar to that of

Alnus sinuata.

The pattern of abundance for Cupressaceae pollen

is different than most of the other arboreal pollen.

Cupressaceae pollen shows two periods of low

concentration centered on 3000 and 1400 b.p with an

intervening peak at about 1900 b.P. Above layer D

Cupressaceae shows a peak at about 800 b.p and a low

value at layer B similar to other species.

Non-arboreal pollen is an insignificant part of

the pollen record at Bull Run Lake. The only 
non-arboreal palynomorphs occurring more than occasionally are monolete and trilete spores. Trilete spores are probably evidence of the fern Pteridium (Barnosky, 1981) and monolete spores of members of the Polypodiaceae (Kapp, 1969).

The concentration of trilete spores is variable, but no trends are discernable. Monolete spores show more long term variability than trilete spores, with peaks at 4400 b.p. and 2700 b.p. After 2700 b.p. there is a general decline until about 1000 b.p. followed by a broad peak. There is a noticable sharp decline corresponding to layer $B$.

Charcoal grains are abundant at all levels in the core. While the number is quite variable, relatively few values fall outside one standard deviation from the mean. High concentrations at 2200 b.p. and 800 b.p. and low concentrations at 1350 b.p. and 300 b.p. (layer B) are the main features of the core.

\section{Diatom Profiles}

Results of diatom analysis are presented in Figure 12. Table XII lists all algal species which were identified.

Like the pollen, diatom concentration does not vary greatly in correspondence with the layers noted in the $x$-radiographs. An exception is at layer $D$ where 


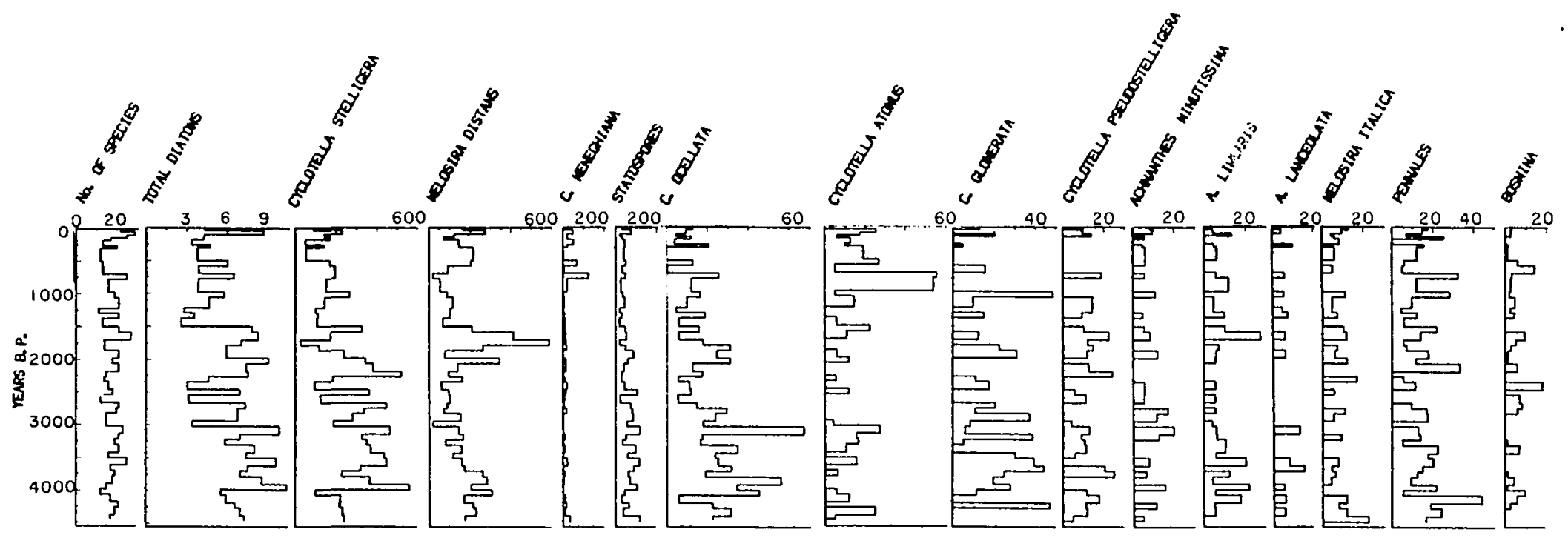

Figure 12. Diatom concentration diggram from

BuIT Run Lake. Concentration in $10^{6}$ frystules/g

dry weight except for total diatoms, $10^{8} / \mathrm{g}$.

Note horizontal scale changes. 
TABLE XII

DIATOMS AND OTHER ALGAE IDENTIFIED IN BULL RUN LAKE SEDIMENTS

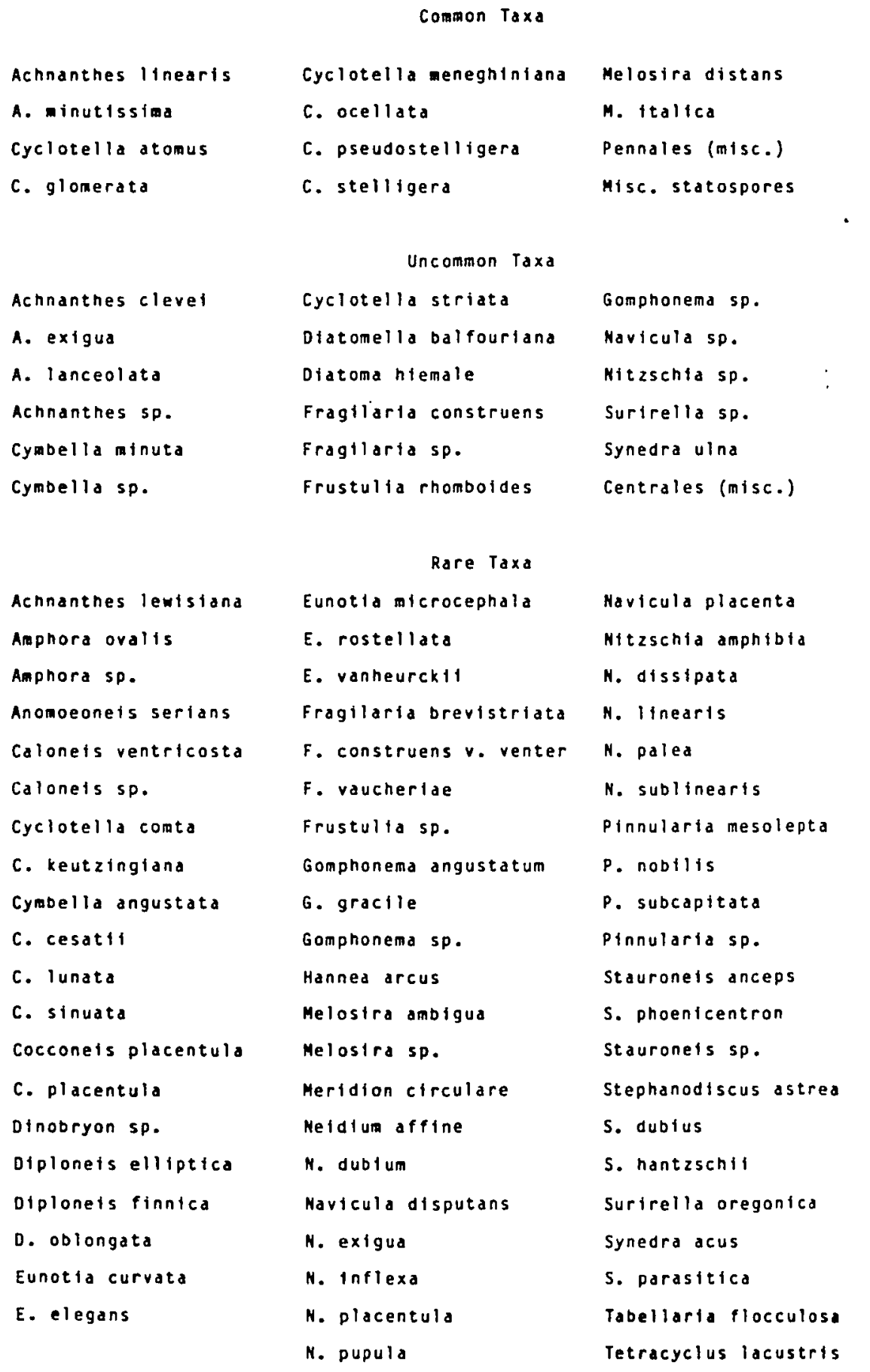


many of the diatom species decrease in concentration.

The total number of diatom frustules shows an initial decline from 4400 to 4000 b.p., a sharp dip in concentration at about 2500 b.p., and another sharp dip coincident with layer $D$. In general the appearance is of two regimes; a period of relatively high diatom concentration prior to layer $D$ and a period of lower diatom concentration subsequent to layer $D$.

The number of species per sample varies about the median value of 18 , but does not show any systematic changes. The number of species noted is particularly low at 3900 b.p., between 1800 and 1600 b.p., and in the region of layer B, from 500 to 250 b.p. The number of species is particularly high only in the most recent sediment.

Several of the individual profiles exhibit a pattern different from the total diatom pattern. Melosira distans increases to a peak in the lower portion of the core, declines to a stable value, then records a dramatic increase peaking at about 1700 b.p. M. distans reaches its lowest concentration between 1500 and 500 b.p., but increases in the more recent sediments. Cyclotella meneghiniana and Cyclotella atomus also increase markedly in the more recent sediments.

Bosmina, a planktonic crustacean, occurs more 
frequently in the sediments after about 2000 years

b.p., but has its greatest concentration at about 2300

b.p. 


\section{DISCUSSION}

\section{Events Influencing Bull Run Lake}

To determine what, if any, changes have occurred in Bull Run Lake as a result of sudden "catastrophic" events in the watershed, any such events must first be identified. A cursory look at the data presented here indicates that there have been times when the sediment constituents have changed rather drastically from the usual values.

The sediments of a lake reflect the composition and condition of the soils in the watershed of the lake (Mackereth, 1966, Tutin, 1969; Brugam, 1978a). The watershed of Bull Run Lake is steep and has sizeable areas of exposed rock. Relatively little weathering of the parent rock takes place before deposttion as part of the sediment. The lack of weathering is confirmed by the very low concentration of clay minerals present in the sediment (Weaver, personal communication). Those clays which are present (smectite) indicate the weathering of volcanic glass. Under these conditions it is likely that the elemental composition of the sediment will bear close resemblance to the rocks in 
the basin.

There have been no analyses of rocks in the Bull Run Lake basin. Representative rocks from areas near Bull Run Lake, outside the basin, have been analyzed. The results of these analyses are presented in Table XIII along with the median elemental concentrations of sediment from Bull Run Lake. While there are similarities of individual elements between various rocks and Bull Run sediment, none of the rocks analyzed seems to be the source of the sediment in Bull Run Lake.

A deviation from the usual value of some parameter in the sediment could be taken as indicating a deviation in the usual value of that parameter in the watershed. There is a large amount of uncertainty in relating the sediment to the watershed, both because of processes of sedimentation and diagenesis, and because of variation introduced by the sampling and analysis. Therefore, we cannot rely on change in only one parameter, but must define an "event" as the occurrence of many large deviations from the usual value. For this purpose it is useful to look at the number of parameters whose value at a particular level in the core lies far from the usual value.

Figure 13 presents the number of parameters below the 25 th percentile and above the 75 th percentile for 
TABLE XIII

TRACE ELEMENT CONCENTRATION FOR VARIOUS ROCKS

IN THE VICINITY OF

BULL RUN LAKE

Concentration (ppm unless noted)

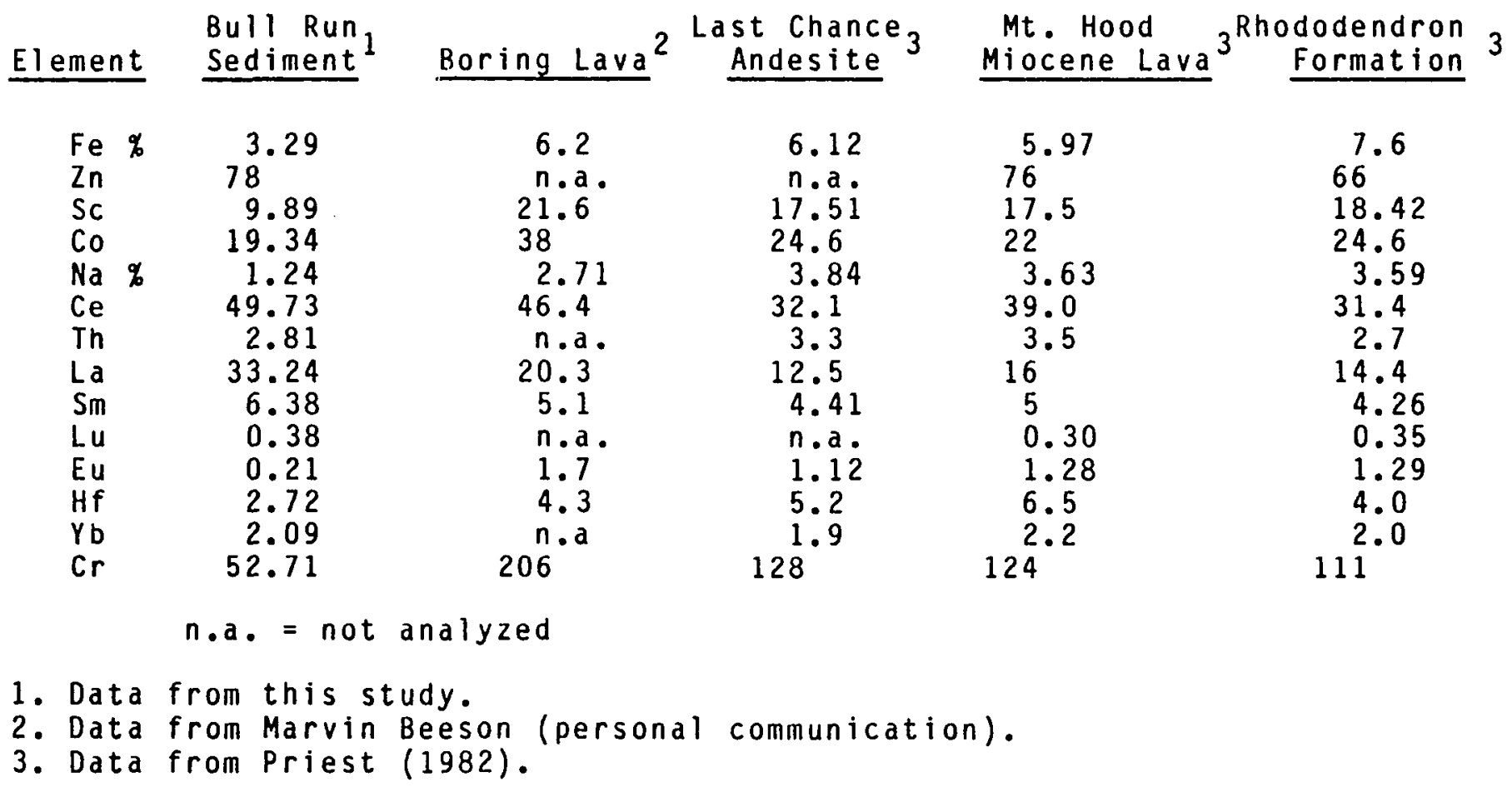




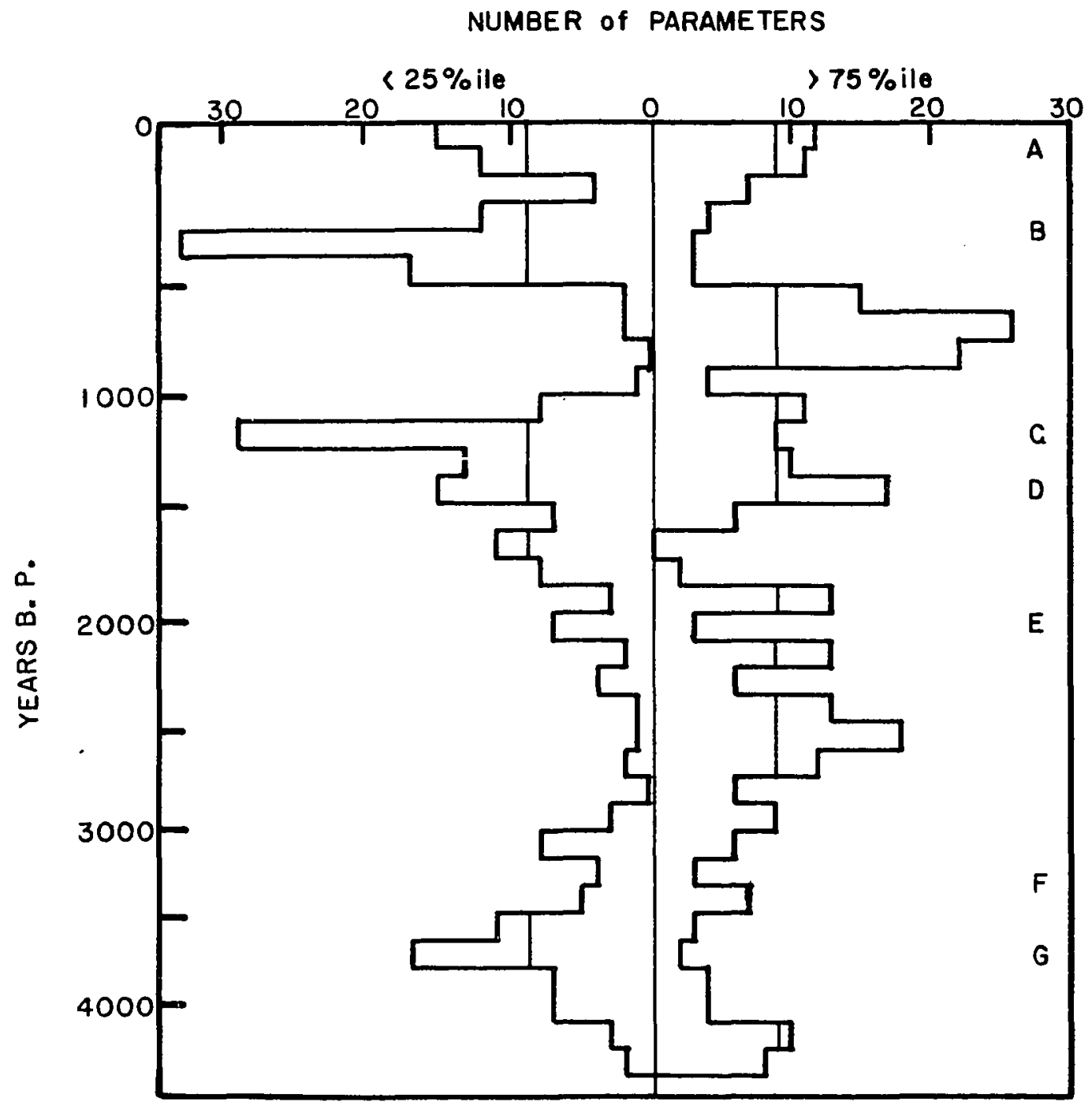

Figure 13. Number of parameters beyond the 25th and 75th percentile. The vertical line cutting the histogram denotes the mean number of parameters exceeding the limits. The vertical axis has been expanded to show detail near the surface. 
each level in the core. Several periods stand out as having more than the mean number of parameters outside the limits. We can define these periods as events based on the requirement of many values far from the usual value. They are presented in Table XIV together with the parameters which are beyond the limits at each period.

To gain some insight into the source of the disturbances resulting in the events noted in Table XIV, it is helpful to look at known events in the region which could have influenced Bull Run Lake. Both Mt. Hood and Mt. St. Helens, to the east and north of Bull Run Lake respectively, have erupted during the period of record. The occurrence of Mt. Mazama ash is direct evidence that distant events can be detected in the sediment.

Material from Mt. St. Helens has been deposited in the Bull Run watershed very recently (Schulters and Clifton, 1980). Ash from Mt. St. Helens has been deposited in the vicinity of Bull Run Lake several times in the last 150 years (Harris, $1976 \mathrm{p} .167$ ). In 1821 and 1835 volcanic ashfall was recorded at Vancouver, Washington, and in 1842 a large ashfall was recorded at Vancouver and as far east as The Dalles, Oregon.

Crandell et al. (1975) and Harris (1976) report 


\section{TABLE XIV}

\section{PARAMETERS GREATER THAN THE 75 th PERCENTILE OR LESS THAN THE 25th PERCENTILE}

\begin{tabular}{|c|c|c|c|}
\hline $\begin{array}{l}\text { Event } \\
\text { Number }\end{array}$ & $\begin{array}{l}\text { Period } \\
\text { (Years b.p.) }\end{array}$ & $\begin{array}{l}\text { Parameters Exceeding } \\
75 \text { th Percentile }\end{array}$ & $\begin{array}{l}\text { Parameters Below } \\
25 \text { th Percentile }\end{array}$ \\
\hline 1 & 0.140 & $\begin{array}{l}\%_{C e}{ }^{H}{ }^{O} \text { Th, } \mathrm{Fe}(\mathrm{AAS}), \mathrm{Br}, \mathrm{H} f, \mathrm{~Pb}, \mathrm{~K}, \\
\end{array}$ & $\begin{array}{l}\text { * LOI, P, Fe(NAA), Co, } \\
\text { Na, La, Sm, Lu, Char- } \\
\text { coal, pollen, diatoms }\end{array}$ \\
\hline 2 & $260-540$ & $\% \mathrm{H}_{2} \mathrm{O}, \mathrm{Br}$ & $\begin{array}{l}\text { \% LOI, P, Fe, Mg, Zn, } \\
M n, P b, K, S C, \text { Co, Na, } \\
\text { Ce, Th, La, Sm, Lu, } \\
\text { Eu, Hf, Yo, Charcoal, } \\
\text { polien }\end{array}$ \\
\hline 3 & $500-900$ & $\begin{array}{l}H_{2} 0, \% \text { LOI, Fe(AAS), } \\
M n, Z n, M g, K, \text { SC, Ce, } \\
\text { Th, Br, La, Sm, Lu, Hf, } \\
\text { Yo, charcod, pollen }\end{array}$ & Diatoms \\
\hline 4 & $1060-1500$ & $\begin{array}{l}\mathrm{Fe}(\mathrm{AAS}), \mathrm{Mg}, \mathrm{Mn}^{\mathrm{M}}, \mathrm{Pb}, \mathrm{K}, \\
\mathrm{Na}, \mathrm{Th}, \mathrm{La}, \mathrm{Hf}\end{array}$ & $\begin{array}{l}\text { \% H }{ }^{O}, \% \text { LOI, } P, \\
\text { Fe (FAA), CO, SC, Br, } \\
\text { Sm, LU, Yo, charcod, } \\
\text { poilen, diatoms }\end{array}$ \\
\hline 5 & $1660-1760$ & & $\begin{array}{l}\text { Fe(AAS), } M g, Z n, K, \\
\text { Sc, Na, Ce, Th, Sm, } \\
\text { LU, Hf, Yb, charcoal, } \\
\text { poilen }\end{array}$ \\
\hline 6 & $1900-1980$ & $\begin{array}{l}\text { \% Lol, } Z n, S c, \text { Co, Lu, } \\
\text { Yb, charcoal, diatoms }\end{array}$ & $\mathrm{Fe}(A A S), K$ \\
\hline 7 & $2080-2220$ & $\begin{array}{l}\text { Mg, Mn, } S c, \text { Co, Na, Lu, } \\
\text { charcoal, diatoms }\end{array}$ & $\% \mathrm{H}_{2}{ }^{0}$, Th \\
\hline 8 & $2340-2740$ & $\begin{array}{l}x \text { LOI, P, Fe(NAA), Pb, } \\
\text { Sc, Co, Ce, Th, La, Sm, } \\
\text { Lu, Eu, Yb, polien }\end{array}$ & $H f$ \\
\hline 9 & $3420-3780$ & Fe (NAA), diatoms & $\begin{array}{l}\text { \% H O, \% LOI, P, } \\
\text { Fe( } R A S) \text {, Mg, Zn, Mn, } \\
\text { PD, K, Na, Th, Br, } \\
\text { Hf, Eu, Charcoal, } \\
\text { polien }\end{array}$ \\
\hline 10 & $4060-4200$ & $\begin{array}{l}P \text {, Fe(AAS), Zn, } P B \text {, } \\
\text { charcoal, pollen }\end{array}$ & $\approx \mathrm{H}_{2} \mathrm{O}, \mathrm{Mn}$ \\
\hline
\end{tabular}


several other events of eruption from Mt. St. Helens during the time of our record. At least one large tephra eruption reached northeast oregon during the period 4100 b.p to 3600 b.p. The Y tephra from Mt. St. Helens was erupted approximately 3500-3350 b.p. Other widespread recognizable tephra deposits from Mt. St. Helens are the $W$ tephra, 440 b.p., and the $T$ tephra, 1800 A.D. In a sediment core from Davis Lake, north of Mt. St. Helens, Barnosky (1981) noted four tephra deposits dated between 4000 b.p. and 2560 b.p. White (1980) and Priest and Vogt (1982) detail the recent eruptive history of Mt. Hood. Two major post-glacial eruptions are the voluminous pyroclastic flows of the Timberline series, about 1700 b.p., and the mudflows and pyroclastics of the $01 d$ Maid flat flows, 250-176 b.p., just south of Bull Run Lake. The Timberline flows were on the south side of the mountain. Harris (1975 p.147) presents evidence for a significant ash eruption in the early 1800 s A.D. and for several minor eruptions between 1859 and 1865 A.D.

Fire is another influence which may result in sudden changes in the sediment profile. Hemstrom and Franklin (1982) have demonstrated the coincidence of large fires in Mt. Rainier National Park with periods of prolonged drought or dry winters. They noted fire episodes using tree ring dating of stands. The largest 
fire, which burned 47 percent of the forested area in the park, occurred in about 1230 A.D., or about 750 years D.P. Between 1403 A.D. and 1628 A.D. (577-350 b.p.) there were three episodes of forest fire, each of which burned approximately 25 percent of the forested area.

Weather regimes in the Pacific Northwest tend to be regional in extent (Johnson and Dart, 1982), so it likely that the droughts which corresponded with fires around Mt. Rainier may have affected Bull Run Lake and its watershed. Evidence of forest fire might be expected in the lake sediment at depths coincident with the periods of extensive fires at Mt. Rainier.

Table XV summarizes the occurrence of known events with the data of this study. There is a striking coincidence of the evidence of disturbance in the Bull Run Lake cores with seyeral of the known events during the period of record. The time correspondence of several events suggests causal relationships, but stronger evidence is needed.

Several investigators have determined trace element concentration of tephras from the Pacific Northwest (Borchardt et al., 1971; Randle et al., 1971; Kittleman, 1979). Figure 14 shows the relationship of Bull Run Lake sediments to tephras from other northwest volcanoes, and Table XVI summarizes data on tephras 


\section{TABLE XV}

\section{HISTORIC EVENTS WHICH MAY HAVE INFLUENCED BULL RUN LAKE}

\begin{tabular}{|c|c|c|c|}
\hline $\begin{array}{l}\text { Event } \\
\text { Number }\end{array}$ & $\begin{array}{l}\text { Perfod } \\
\text { (Years b.p.) }\end{array}$ & Historic Events & Events this study \\
\hline 1 & $0-140$ & $\begin{array}{l}\text { Mt. St. Helens tephra T } \\
\text { Eruptions of Mt. Hood } \\
\text { and Mt. St. Helens }\end{array}$ & Layer A \\
\hline 2 & $260-540$ & $\begin{array}{l}\text { Mt. St Helens tephra } W \\
\text { old MaidFlat mudflows }\end{array}$ & $\begin{array}{l}\text { Layer } 8 \\
\text { Charcoal minimum }\end{array}$ \\
\hline 3 & $500-900$ & Large fires at Mt. Rainier & Charcoal maximum \\
\hline 4 & $1060-1500$ & --- & $\begin{array}{l}\text { Layer } C \\
\text { Layer D } \\
\text { Density maximum }\end{array}$ \\
\hline 5 & $1660-1760$ & Timberline pyroclastics & Charcoal peak \\
\hline 6 & $1900-1980$ & --- & $\cdots$ \\
\hline 7 & $2080-2220$ & $\begin{array}{l}\text { Mt. Hood mudflows } \\
\text { Increased glaciation in } \\
\text { Sierras }\end{array}$ & Broad charcoal peak \\
\hline 8 & $2340-2740$ & $\begin{array}{l}\text { Davis Lake tephra I } \\
\text { Davis Lake tephra II }\end{array}$ & Layer E \\
\hline 9 & $3420-3780$ & $\begin{array}{l}\text { Davis Lake tephra III } \\
\text { Mt. St. Helens tephra y }\end{array}$ & $\begin{array}{l}\text { Layer } \mathbf{F} \\
\text { Layer } \mathbf{G}\end{array}$ \\
\hline 10 & $4060-\$ 200$ & Davis Lake tephra IV & --- \\
\hline
\end{tabular}




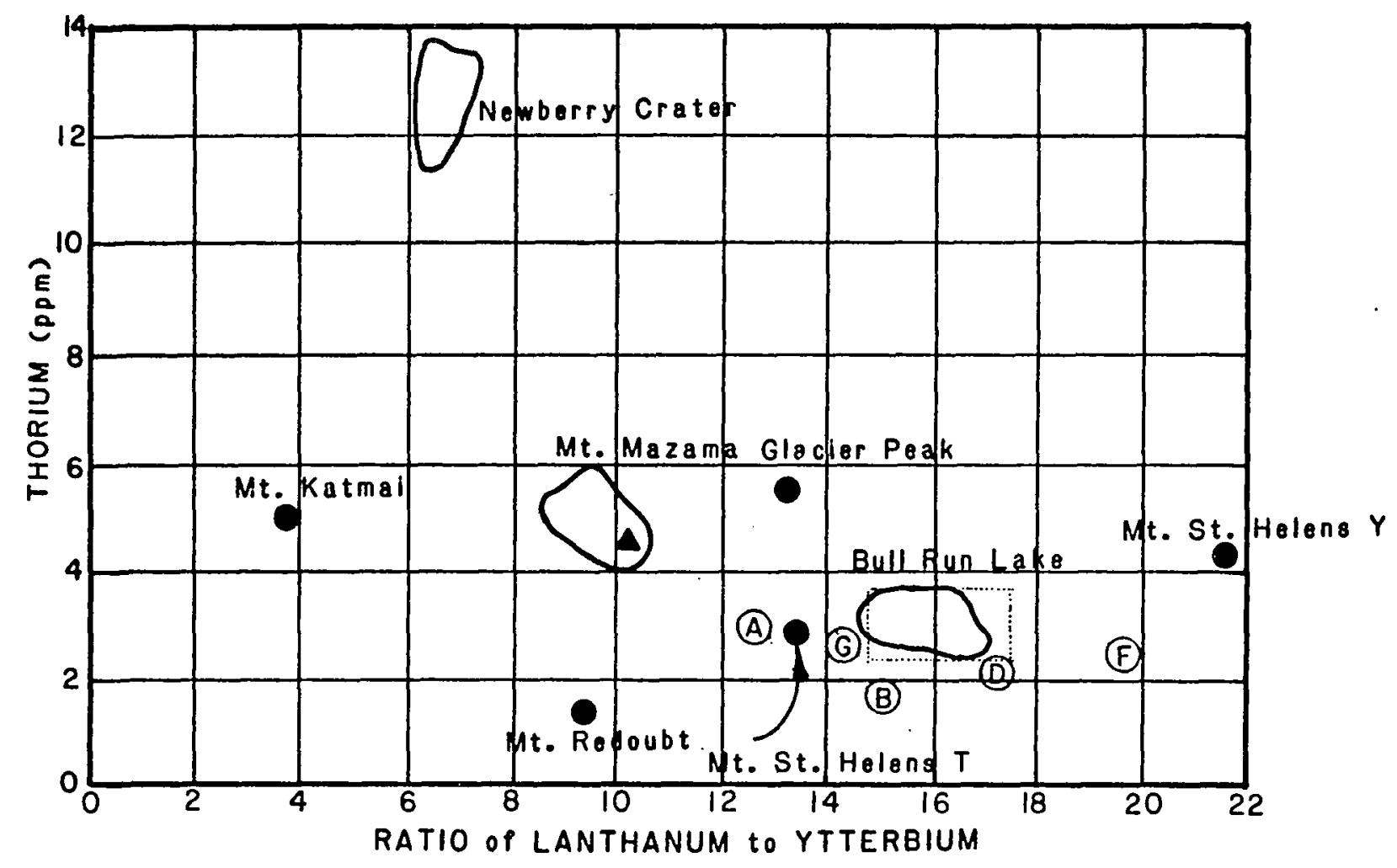

Figure 14. Plot of thorium vs. La/Yb for several northwest volcanoes (modified from Kittleman, 1979). Solid triangle is the ash sample from Bull Run Lake, solid circles represent analyses of a single tephra sample. Letters within circles represent analysis of $x$-ray layers from Bull Run sediment. The solid line surrounds $75 \%$ of the Bull Run samples; the dotted rectangle covers the mean plus one standard deviation. 
TABLE XVI

ELEMENT CONCENTRATION OF MT. ST. HELENS TEPHRA AND BULL RUN

LAKE SED IMENT

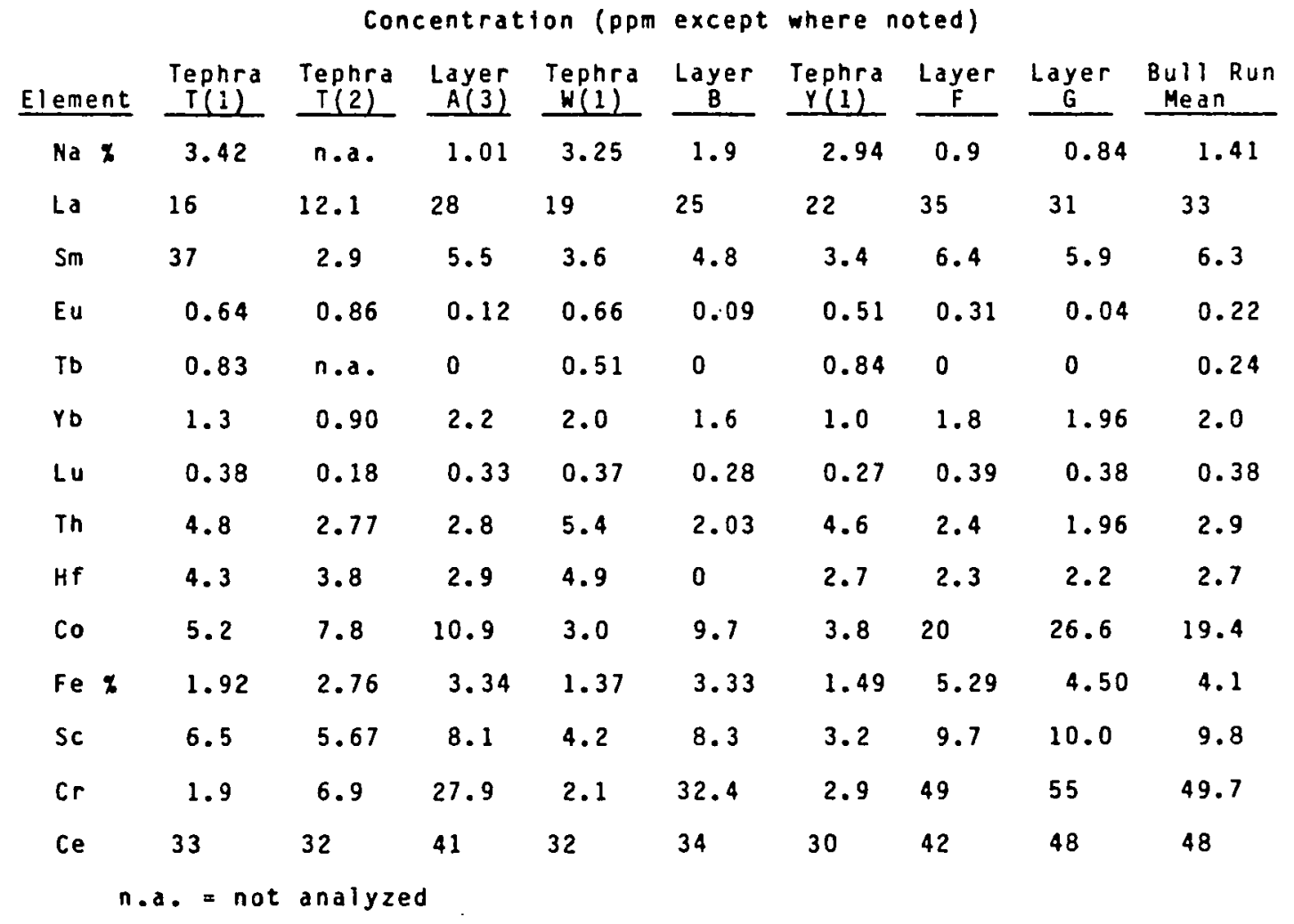

1. Analysis of glass separates by Borchart et al. (1971).

2. Analysis of bulk tephra by Randle et al. (1971).

3. This study. 
from Mt. St. Helens and sediment from Bull Run Lake. Hutchinson and Cowgill (in Hutchinson, 1970) compared the sediment of a lake with the volcanic rocks surrounding it to determine the fate of elements comprising the rocks. They found that in general, $K$, $\mathrm{F}, \mathrm{Na}, \mathrm{Sr}$ and $\mathrm{Ba}$ are lost from the rocks in early weathering processes, and consequently are depleted in the sediment relative to the parent rocks. Calcium, $\mathrm{Na}, \mathrm{Rb}$ and Sr are lost in erosion and deposition of the sediment, and are also depleted in the sediments. Sulfur, $C l$ and $B r$ are enriched in the sediment. The source of bromine is the atmosphere via precipitation. Among the lanthanides, La and Hf are conservative and the remainder, with the exception of $\mathrm{Sm}$, are leached only slowly. Samarium may be abnormally mobile among the lanthanides.

The mobility of iron and manganese is influenced by the redox potential of the soil or sediment (Anthony, 1977). Under oxidizing conditions iron and manganese move only in the particulate phase. Under reducing conditions first manganese, then iron, becomes soluble and is leached, to be precipitated again under oxidizing conditions.

It is now evident that the division of elemenis into Groups 1,2 and 3 , based on correlation analys is, divides the elements generally into those elements 
which are leached from the rocks during weathering (Group 2) and those which tend to be conservative (Group 1). The noticeable exceptions are thorium and hafnium in Group 2. Both of these elements tend to move with the particulate fraction (Beeson, personal communication). It is now possible to indicate the nature of the disturbances which have produced events in the sediment.

Event number $1,0-140$ b.p., and containing layer A, appears to reflect the influence of Mt. St. Helens tephra T. This conclusion is based on the close time correlation and the similarity of the thorium concentration and the La/Yb ratio, illustrated in Figure 13. The relatively high amount of thorium, hafnium and potassium combined with the low values for several of the rare earths, pollen, diatoms, and charcoal indicate that there has been some mass input of unweathered material.

This period has been one of considerable volcanic activity in the vicinity with reported eruptions of both Mt St. Helens and Mt. Hood. It is likely that the input from the $T$ tephra has been modified by other occurrences during the period. Another event which could be the result of activity of Mt. St. Helens is number 9, 3780-3420 years b.P., containing layer $F$ and $G$. Layer $F$ corresponds in 
time to tephra 3 from Davis Lake, to the $y$ tephra from Mt. St. Helens, and to a peak in the density of the sediment indicating an increase in the mineral content of the sediment. The concentration of thorium and the La/yb ratio place the event well outside the normal range of Bull Run sediment in the direction of the $Y$ tephra (Figure 14).

The large increase in sodium at this level in the cores indicates an input of unweathered material. Layer $G$ does not correlate well with any known historical event, nor is there any great perturbation of the elemental composition. At this time layer $G$ is unexplained.

Event number $2,540-260$ b.p., containing layer $B$, coincides in time with several known events; Mt. St. Helens W tephra, the 0ld Maid Flat mudflows from Mt. Hood, and several periods of extensive drought and fire at Mt. Rainier. The elemental concentrations in Layer B do not correspond well with those of the $W$ tephra, making it unlikely that layer B resulted from that event. In addition, during this period the abundance of charcoal grains in the sediment reaches its lowest level in the record. Sodium, potassium and magnesium all increase sharply in this interval while most other parameters, including total pollen and total diatoms, decrease. This indicates an influx of unweathered 
material which may have come from pyroclastic events associated with the 0ld Maid Flat mudflows.

In the other events which correlate with the time of known volcanic activity (events 5, 7,8 and 10) there is not sufficient evidence to link the sediment event with the volcanic event. Sediment event 5 (1660-1760 b.p.), which corresponds with the timberline pyroclastic flows on Mt. Hood, shows a noticeable decrease in the conservative elements (Group I) and a slight increase in sodium. This indicates some dilution of the normal rock material, and perhaps an input of unweathered material.

Event 7 (2220-2080 b.p.), which corresponds to the time of mudflows from Mt. Hood, shows a sharp increase in most of the elements of Group 2, indicating an input of unweathered material.

An event with a different nature is number 3 (900-500 b.p.). This digression corresponds with no known eruptive event in the vicinity. The pattern of elemental variation is somewhat different from the other events. There is an increase in many of the elements in Group 1 , but no corresponding increase of elements in Group 2. Iron and manganese are exceptions which increase markedly. The impression is of an increased input of weathered material perhaps as the result of erosion. The change in iron and manganese 
could indicate a change in the reducing conditions in the soil (Hutchinson, 1970; Mackereth, 1966). The sudden increase in the abundance of charcoal grains and the peak in phosphorus concentration combine with the other data to indicate the occurrence of a major fire in the vicinity of Bull Run Lake. Charcoal peaks have been clearly associated with fire in forested watersheds (Swain, 1973; 1978; Terasmae and Weeks, 1979). Other studies have shown that phosphorus and sediment loss increased on burned watersheds (Schindler et al., 1980; Tiedemann et al., 1978; 1979; Wright, 1976; Bradbury et al., 1975), but losses of calcium, magnesium and sodium did not (Wright, 1976).

Hemstrom and Franklin (1982) found evidence of a major fire in the vicinity of Mt. Rainier during this same time period and attributed it to drought based on the connection of several younger fires with periods of drought or dry winters. The evidence for a fire in the Bull Run Lake watershed corroborates the findings of Hemstrom and Franklin, and indicates a period of drought and widespread forest fire in the Pacific Northwest about 750 years ago.

Event number 4 (1500-1060 b.p.), containing layers $C$ and $D$, is perhaps the most unusual of all. It corresponds to no known volcanic or fire event, yet is the most dramatic event in the sediment record. Abrupt 
changes are evident in nearly every parameter including the pollen and diatoms. The layers noted are the most distinctive ones on the $x$-radiographs, and were the most noticeable in the intact cores.

Most of the mobile elements increase, suggesting input of unweathered material, while most of the conservative elements decrease, suggesting dilution of the parent material. The thorium concentration and the La/Yb ratio are within the limits of most of the samples of Bull Run sediment. Pollen, diatom and charcoal abundance all decrease.

Layers $C$ and $D$ have the largest amount of crystalline material (albite and quartz) of any of tho samples analyzed, and had a decidedly inorganic, clay-like character when extruded. The layers were also notable for the quantity of large, undecomposed organic items present, including needles, leaves, wood chips, and fibrous material.

Layers $C$ and $D$ appear to have arisen from a local event, perhaps confined to the Bull Run Lake watershed. The pattern of elemental changes and the absence of charcoal fragments indicate that there was a large input of inorganic material from the watershed, associated with greater than usual amounts of large organic debris. Until further investigation is made, the exact nature of this disturbance will remain 
unknown, but the most likely event would appear to be a landslide or avalanche. The terrain of the watershed is suitable for these events.

One aspect of the changes in element concentration in the core, which does not stand out in relation to other changes, but which may indicate a phenomenon of great importance in the future, is the sudden change in lead concentration at the surface of the core. The most likely new source of lead in the Bull Run basin is airborne material of anthropogenic origin. Independent evidence of the possible influence of airborne pollutants on Bull Run lake was obtained on one coring expedition. Floating on the lake were several heart-shaped mylar balloons which had been sold in great numbers in Portland at a city fair the day before.

\section{Pollen and Vegetation}

There have been several studies of pollen profiles in the Pacific Northwest west of the Cascades. For the most part they have been concentrated in the Puget lowlands (Barnosky, 1981; Tsukada et al., 1981, Hansen and Easterbrook, 1974, Heusser, 1973; 1977), and directed toward establishing the long term climate sequence following the retreat of the glaciers (Hansen, 1947 ; Heusser and Heusser, 1980; Heusser et a 1., 1980). 
Some work has been done to describe the effect of changing land use on the pollen spectrum (Davis, 1973). Most of these previous efforts have been directed at the long term, low frequency variation in environmental conditions. The purpose of the present study is to determine the effect of short term discuption. The period of our record has been considered by palynologists to be one of rather constant conditions of cool, moist climate with a forest vegetation similar to the present (eg. Barnosky, $1981)$.

The pollen diagram from Bull Run Lake conforms to this view. With the exception of Pinus, which declines steadily in abundance between about 2400 b.p. and 1700 b.p., the pollen curves show basically a stable trend punctuated by occasional digressions.

There are several points of congruence between the pollen curves and the events noted in consideration of the trace element data. Events 1 and 2, corresponding to layers $A$ and $B$ show a sharp decline in abundance of all species and in the total pollen count. This universal decline argues against some disruption in the vegetation, but rather that the pollen influx was diluted by some other input. This, combined with the LOI data at layers $A$ and $B$, supports the view from the element analysis that these two events represent 
some allochthonous input to the watershed, probably from a nearby volcanic event.

The older events identified in the trace element data (events 5 through 10) do not show any consistent pattern in the pollen. It is unlikely that any of these events had a significant impact on the forest vegetation around Bull Run Lake.

The most complex series of changes in the pollen record begins at about 1400 b.p. with a sharp decline in total pollen, and corresponding deciines in most of the species. After a very short interval where most of the species recover to higher concentrations, there is another general decline in pollen abundance at about $1200 \mathrm{~b} . \mathrm{P}$. These two declines correspond to layers $D$ and $C$ in the $x$-radiographs, and to event 4 from the element data. As at layers $A$ and $B$, these declines are consistent with an increase in the inorganic input, resulting in dilution of the pollen rain.

The events at layers $C$ and $D$ are different from the events at Layers $A$ and $B$ however, in that the $C / D$ event seems to have had a marked influence on the vegetation as recorded in the pollen curves. Immediately following the $C / D$ event there is a rapid increase in pollen concentration of several species, resulting in the highest total pollen concentration value in the record. 
The pattern of these increases suggests a forest recovering from a major disruption (Franklin and Dryness, 1973). First come the pioneer species Alnus sinuata and Alnus rubra followed by the longer lived pioneer species Pinus and Douglas-fir. As these species reach their peak abundance, the longer lived climax species of Abies and Tsuga heterophylla begin to increase to reach a peak at about 750 b.p. By this time pine has decreased to near its earlier abundance, and alder has begun to decline as well.

At 750 b.p. there is a large and sharp peak in charcoal abundance. Subsequent to this peak T. heterophylla and Douglas-fir decline, alder continues to decline, but pinus shows a brief resurgence from an otherwise steady decline.

These changes in the pollen record are consistent with the previous interpretation of the element data; a large, local disruptive event in the watershed resulting in the deposition of mineral and organic debris in the lake. Subsequent to this event, the forest recovered until fire occurred in about $750 \mathrm{~b} . \mathrm{p}$. , altering the successional process. Since that time the forest has been relatively undisturbed, and is returning to a status similar to that before the $C / D$ event.

A smoothed curve of total pollen concentration 
(Figure 15) reinforces the notion of a return to normalcy, and emphasizes the unique nature of the digression at 750 b.P.

Over the period of record from the Bull Run Lake cores, the pollen assemblage has stayed relatively uniform. There is some evidence of response to long-term environmental change in the decline of pine pollen beginning about 2400 b.p., but no convincing evidence of response to any of the recognized volcanic events. The most noticeable change in the pollen spectrum at Bull Run Lake has been in response to disturbance and fire about 750 years ago.

Diatoms and Water Quality

While the pollen record provides a history of changes within the watershed, the record of the diatoms provides the best indication of changes in conditions within the lake itself. The nature of the sediments can also provide information about the changes within the lake, but the sediment matrix can be influenced by events outside of the lake (Brugam, 1978; Mackereth, 1966; Edmondson, 1978) or even, as we have seen for Bull Run lake, by events far removed from the watershed.

The diatom assemblage recorded in the sediment of Bull Run lake fits closely the oligotrophic diatom 


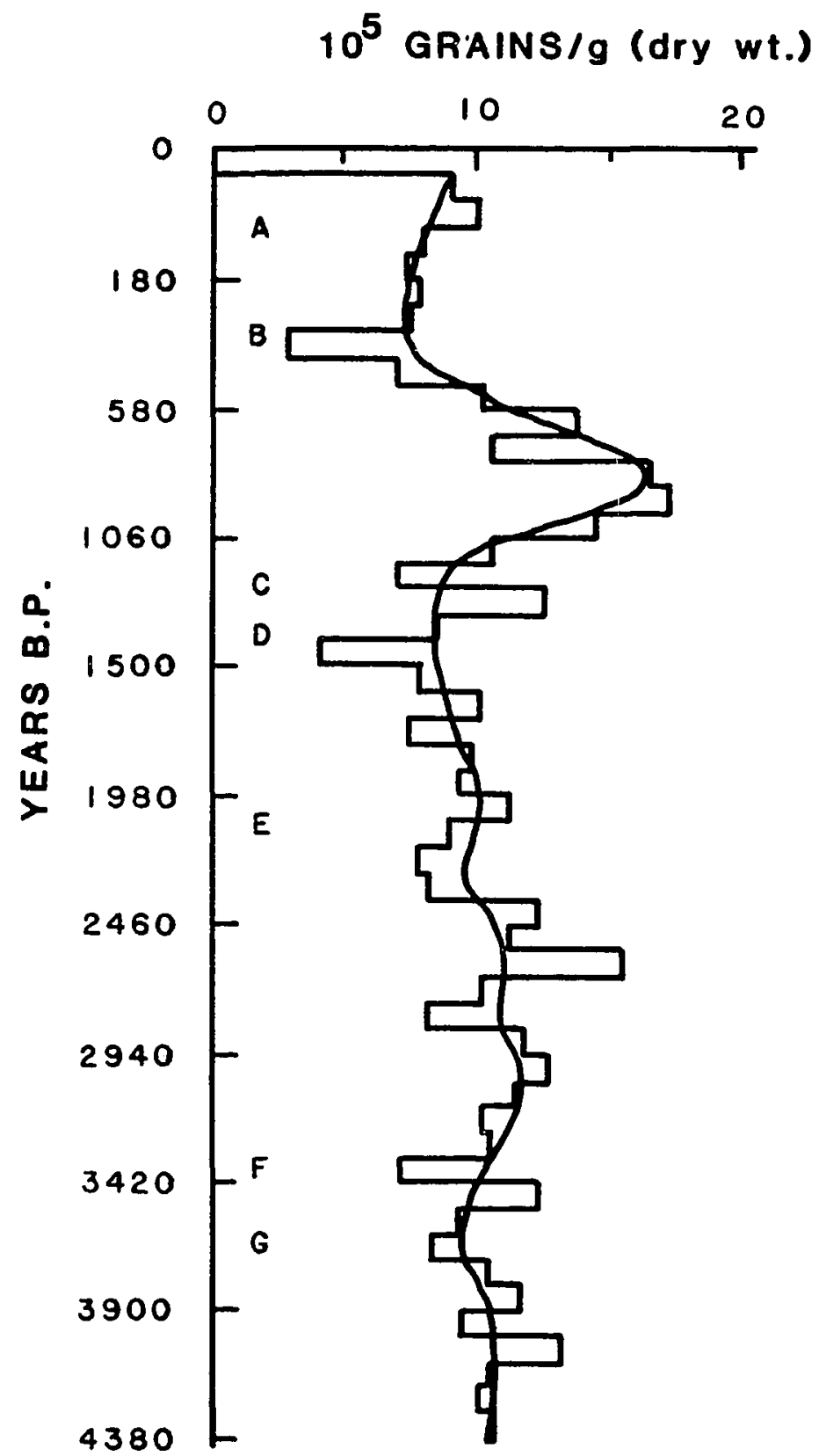

Figure 15. Smoothed curve of total pollen concentration from Bull Run Lake. Histogram presents the raw data. 
association of Hutchinson (1967 p.385), found in the clear, less chthoniotrophic mountain lakes of Finland, and in similar north temperate lakes. This association is dominated by Cyclotella species, especially Cyclotella stelligera and cyclotella keutzingiana, and by Melosira distans.

According to a compilation of available ecological information on diatoms (Lowe, 1974), most of the species found in the Bull Run Lake sediment are planktonic and live best in oligotrophic lakes with neutral to acid water. The specifically stream species which are occassionally found, such as Achnanthes lanceolata, probably originate in the tributary streams.

Crabtree (1969), in a paleolimnological study of Welsh lakes, noted an increase in species of Cyclotella, Achnanthes and Nitz:jchia as the lakes became more oligotrophic. In cligotorphic lakes in Canada, studied by Smol and Dickman (1981), Cyclotella stelligera was the dominant diatom for 12,000 years before discuption of the lakes by road building in the watershed.

Other paleolimnological studies have dealt with long-term, gradual changes such as climate change (eg. Brugam, 1980; Bradbury, 1971) or with sudden but long lasting changes such as effects of human disturbance 
(Hutchinson, 1970; Smol and Dickman, 1981; Bradbury and Waddington ; 1973; Brugam, 1978).

In contrast to the lakes in these studies, Bull Run Lake has not experienced the types of changes and impacts previously studied. Rather, the impacts at Bull Run Lake have been mostly sudden and of short duration. With the possible exception of forest fire, the impacts have occurred as momentary digressions in a generally stable system. This has been seen in the trace element data and in the pollen data, and is also the case with the diatoms.

The pattern of diatom abundance in the sediment of Bull Run Lake suggests nearly constant conditions of oligotrophy for the past 4000 years. With two exceptions, outside perturbations noted in the sediment chemistry record have no parallels in the diatom record. This is emphasized by the smoothed curve of total diatom abundance (Figure 16) which shows the long term stability of the system as well as the two instances where there is a correspondence between the sediment chemistry record and the diatom record. At about 2500 b.p., corresponding to event number 8 and layer $E$, there is a sharp drop in the total diatom abundance. Again at about 1500 b.p., corresponding to event 4 and layers $C$ and $D$, there is another sudden decrease in diatom abundance which has persisted until 


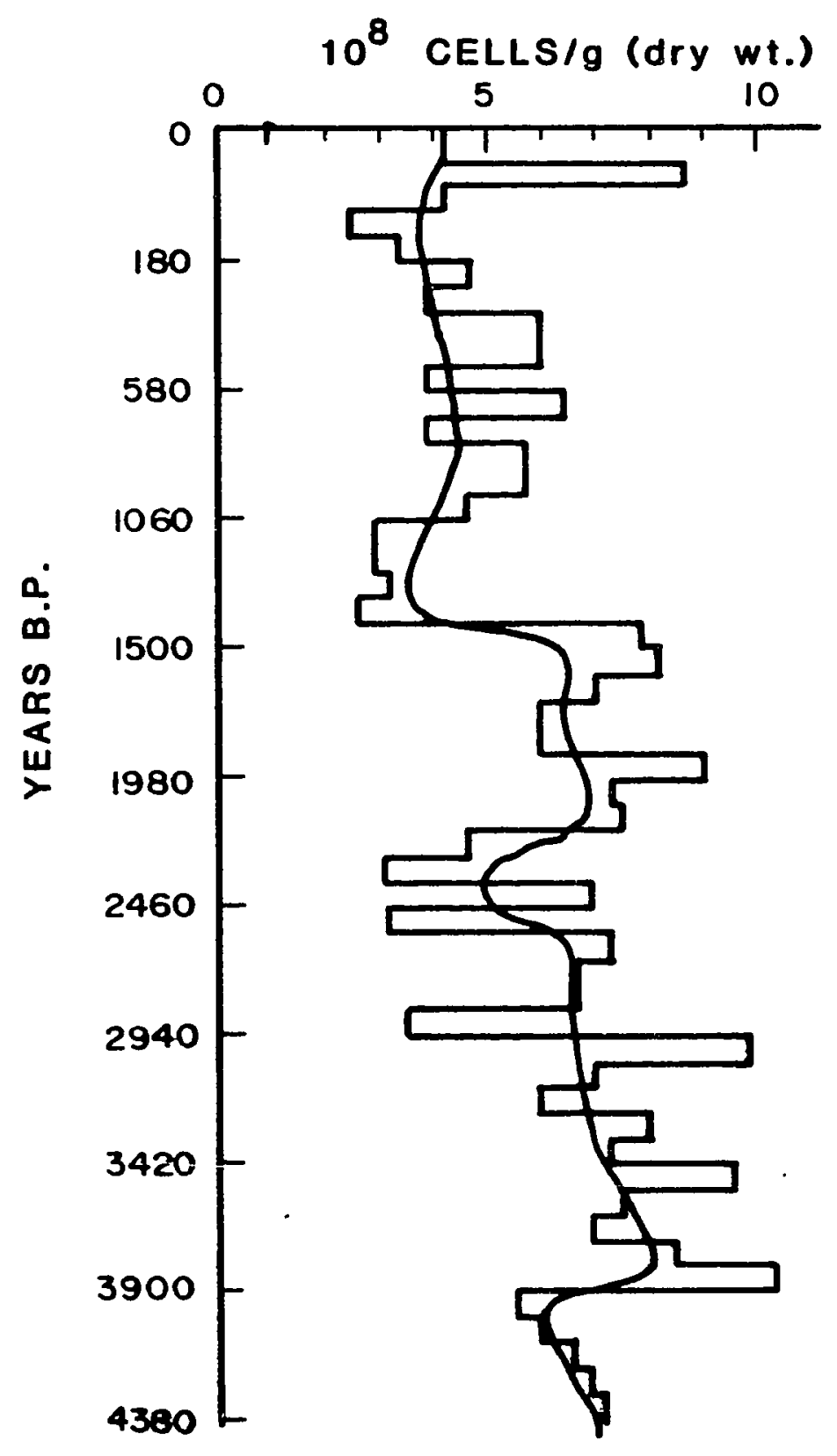

Figure 16. Smoothed curve of total diatom concentration from Bull Run Lake. Histogram shows the raw data. The vertical axis has been expanded to show more detail at the surface. 
the present.

The more recent decline in total diatom numbers is a reflection of a decrease in the abundance of Cyclotella stelligera and a less pronounced decline in Melosira distans. It appears to reflect a decrease in the productivity of the lake. A decrease in concentration resulting from increased input of allochthonous material would be reflected in a decrease of all species, and in the data for trace elements and LOI. None of these other indicators are present. of the diatom species comprising a major portion of the flora, only cyclotella stelligera shows a severe decline. All the others either remain stable, or increase.

Notable in the diatom diagram, and chiefly responsible for the high concentration of total diatoms from 2000 to 1500 b.p., is the dramatic rise in Melosira distans. The other changes occurring in the sediment record at this time suggest an input of material to the lake from an outside source, perhaps related to volcanic activity on Mt. Hood.

An input of material, if it were relatively high in silicon, could provide an explanation for the increase in M. distans. Several studies have shown that diatoms, especially heavily silicified ones, can be limited by low silicon (Tilman and Kilham, 1976; 
Schelske et al., 1975, Kilham, 1971). Kurenkov (1966) observed a dramatic increase in phytoplankton growth following a volcanic ash fall in Alaksa. If diatoms requiring greater amounts of silicon are also better at utilizing it when it is present in higher concentration as proposed by Kilham (1971), an input of volcanic material high in silicon may have contributed to the higher growth of Melosira distans. of particular interest is the increase in concentration of Cyclotella meneghiniana beginning about 700 b.p. Cyclotella meneghiniana achieves its best growth in polluted water (Patrick, 1973), especially in warm water enriched with organic matter or agricultural runoff (Bradbury, 1971). It is periphytic, and has been found in sediment cores in Lake Erie both before and after eutrophication (Harris and Vollenweider, 1982).

Bull Run Lake has not been organically enriched or influenced by agricultural runoff during its history, but the association of the increase of $c$. meneghiana with the period of major fire in the basin suggests that conditions may have changed enough to facilitate growth of a more eutrophic diatom. This period is also one of increased input of manganese to the sediment. Rushforth et al. (1981), in a study of the effect of dissolved metals on diatom populations, 
noted that $C$. meneghiana was found preferentially in conditions of high concentration of manganese.

There are other changes in diatom abundance

evident in the sediment record. Cyclotella ocellata decreases in abundance after about 3000 b.p. Cyclotella stelligera was present in two forms in the core samples which were counted separately, but grouped together for analysis. One form had the diagnostic star in the central area, and the other form lacked the star. The ratio of these two forms change dramatically over time (Figure 17). These and other changes remain unexplained. There is not sufficient evidence to attribute them to any specific event or change in the watershed.

Data were collected on cladoceran remains (Bosmina species) in the sediment. The data are too sparse to allow definitive conclusions to be drawn.

The results of diatom analysis of sediment cores at Bull Run Lake present a picture of long-term stability of an oligotrophic system for the past 4000 years. There is no strong evidence that short term catastrophic events have had any marked long-term effect on the water quality in the lake.

There have been changes in the diatom flora demonstrating the response of individual taxa to changing conditions, but there has been no change in 


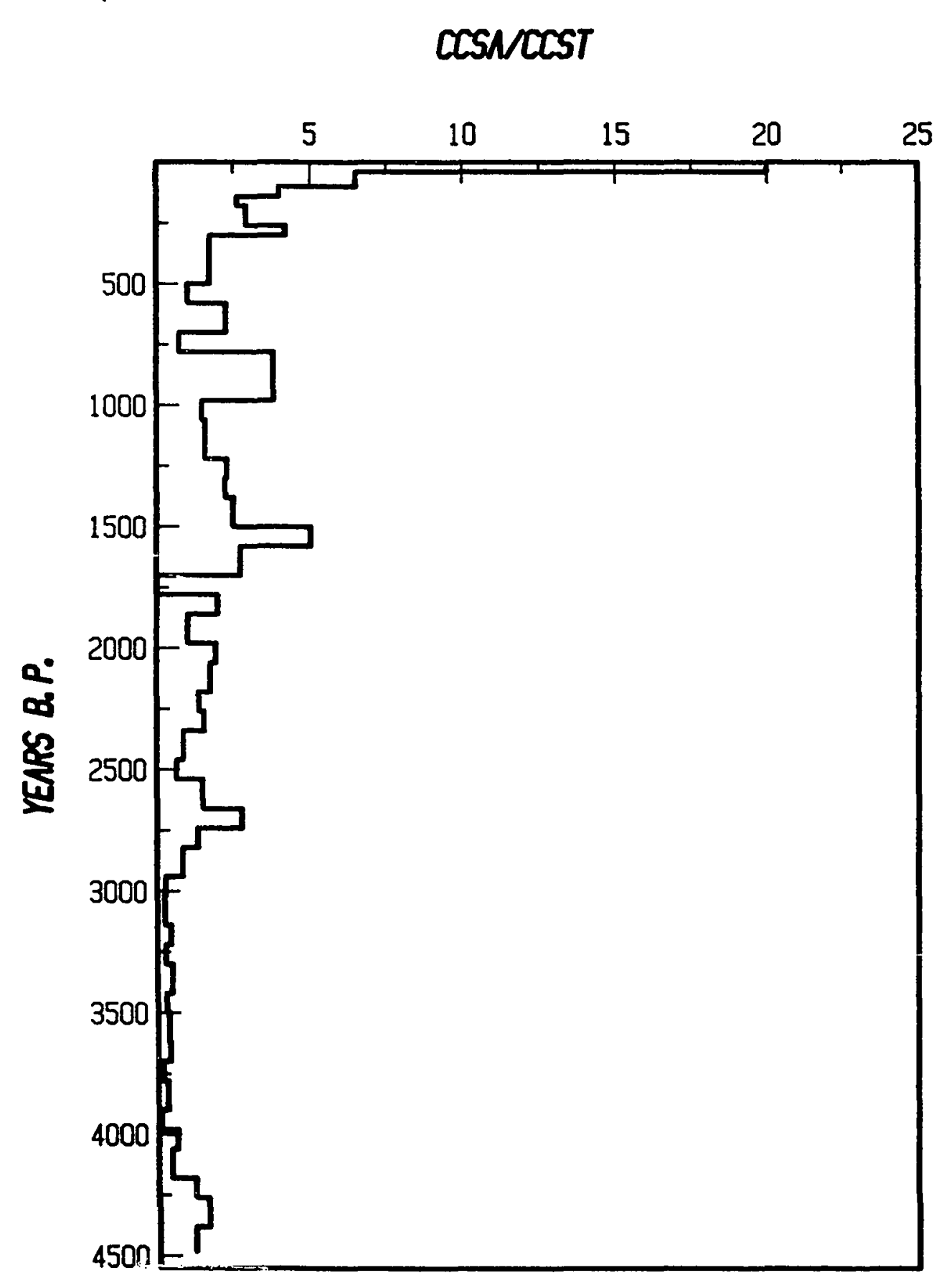

Figure 17. Ratio of Cyclotella stelligera without star (CCSA) toc. stelligera with star (CCST). 
the overall association during the period of record. There appears to have been a decline in the productivity of the lake as evidenced by a decline in the total diatom concentration in the sediment since approximately 1400 years b.p. 


\section{SUMMARY}

Physical and chemical analysis of sediment from Bull Run Lake has shown that on at least 10 occasions in the past 4500 years perturbations occurred in the watershed of sufficient magnitude to induce a measurable alteration in the composition of the sediment. Several of the perturbations resulted in changes in the physical structure of the sediment and in its $x$-ray density.

Some of the perturbations can be correlated with known historic events in the area surrounding Bull Run Lake. The evidence is particularly strong ihat tephras $Y$ and $T$ from Mt. St. Helens and material from events associated with the old Maid Flat mud flows from Mt. Hood were deposited in Bull Run Lake.

There is no evidence that any of the regional volcanic events identiffed in the sediments has had any long term effect on the vegetation surrounding Bull Run Lake, as measured by the pollen deposition, or on the water quality of Bull Run Lake, as measured by the diatoms . 
A major local event of unknown character, most likely an avalanche or landslide, deposited a large amount of material in Bull Run Lake, and had a significant impact on the vegetation surrounding the lake. Evidence from the sediment shows that about 750 years ago a large fire occurred in the vicinity of Bull Run Lake.

There have been minor fluctuations in the diatom community of Bull Run Lake over the past 4000 years, but there is no evidence of a change from the present state of oligotrophy. Some evidence indicates that the overall productivity of the lake has declined in the past 1000 years, and that conditions may have changed following the large fire in $750 \mathrm{~b} . \mathrm{P}$. to permit the temporary increase of more eutrophic diatoms. The overriding impression from sediment analysis at Bull Run Lake is one of long term stability and homeostasis. Momentary or catastrophic disruption such as volcanic ash fall or forest fire have not led to long term or continuing alteration in the overall stability of the Bull Run Lake ecosystein. On the contrary, the trend has been to reestablish the system in a form similar to what existed before the disruption. 
Because the time resolution of this study is on the order of 50 to 100 years, it is possible that very short term effects of disruption, lasting on the order of months or years, have not been detected. 


\section{REFERENCES CITED}

Additon, M. K. and R. 0. Seil. 1979. Columbia river basalt reference sample RHO-SA-93. U.S. Department of Energy, EY-77-C-06-1030. Rockwell International, Richlind, WA.

Alhonen, $P$. 1979. The sedimentary record of the cultural eutrophication and pollution of lakes in Finland. Arch. Hydrobiol. 86(1): 13-26. American Public Health Association. 1979. Standard Methods, 14th Edition.

Anthony, R. S. 1977. Iron-rich rhythmically laminated sediments in Lake of the Clouds, northern Minnesota. Limnol. Oceanogr. 22(1): 45-54. Averett, R. C., S. L. Ponce and D. W. Schindler. 1980. Bull Run Watershed Water Quality Management. Report to the Bull Run Advisory Committee, Portland Water Bureau. Barnosky, C. W. 1981. Quaternary Research Center, University of Washington, Seattle. Personal Communication. Barnosky, C. W. 1981. A record of late Quaternary vegetation change from Davis Lake, southern Puget 
Lowland, Washington. Quat. Res. 16(2): 221-239. Baxter, M. S., J. G. Farmer, I. G. Mckinley, D. S. Swain and W. Jack. 1981. Evidence of the unsuitability of gravity coring for collecting sediment in pollution and sedimentation rate studies. Env. Sci. Tech. 15(7): 843-846. Beaulieu, J. D. 1974. Geologic hazards of the Bull Run Watershed, Multnomah and Clackamas counties, Oregon. Bulletin 82, Oregon Department of Geology and Mineral Industries.

Beeson, M. H. 1980. Department of Geology, Portland State University. Personal communication. Bernabo, J. C. 1982. Quantitative estimates of temperature changes over the last 2700 years in Michigan based on pollen data. Quat. Res. 15(2): 143-159.

Birks, H. H., M. L. Whiteside, D. M. Stark and R. C. Bright. 1976. Recent paleolimnology of three lakes in northwestern Minnesota. Quat. Res. $\underline{6}(2): \quad 249-272$.

Borchardt, G. A., M. E. Harward and R. A. Schmitt. 1971. Correlation of volcanic ash deposits by activation analysis of glass separates. Quat. Res. 1: $247-260$.

Bortleson, G. C. 1970. The chemical investigation of recent lake sediments from Wisconsin lakes and 
their interpretation. Ph. D. Thesis. University of Wisconsin, Madison, WI.

Bortleson, G. C. and G. F. Lee. 1972. Recent sedimentary history of Lake Mendota, Wisconsin. Env. Sci. Tech. 6(9): 799-808.

Bradbury, J.P. 1971. Ecology of freshwater diatoms. Transcript of a symposium.

Bradbury, J. P. 1971. Paleolimnology of Lake Texcoco, Mexico: Evidence from diatoms. Limnol. Oceanogr. 16(2): 180-200.

Bradbury, J.P. and J. C. B. Waddington. 1973. The impact of European settlement on Shagawa Lake, northeastern Minnesota, USA. Quaternary Plant Ecology, H. J. B. Birks and R. G. West, Eds. Halsted Press.

Bradbury, J. P., S. J. Tarapchak, J. C. B. Waddington and R. F. Wright. 1975. The impact of a forest fire on a wilderness lake in northeastern Minnesota. Verh. Internat. Verein. Limnol. 19: $875-883$.

Brugam, R. 8. 1978. Pollen indicators of land-use change in southern Connecticut. Quat. Res. 9: $349-362$.

Brugam, R. B. 1978a. Human disturbance and the historical development of Linsley Pond. Ecology 59(1): $19-36$. 
Brugam, R. B. 1980. Postglacial diatom stratigraphy of Kirchner Marsh, Minnesota. Quat. Res. 13: $133-146$.

Burns, R. 1976. Final judgement and decree. District Court of Oregon, Civil No. 73-609. Colinvaux, P. A. 1978. On the use of the word "absolute" in pollen statistics. Quat. Res. g(1): $132-133$.

Collins, G. B. and R. G. Kalinsky. 1977. Studies on Ohio Diatoms: I. Diatoms of the Scioto River Basin. II. Referenced Checklist of Diatoms from Ohio. Bull. Ohio Bioloical Survey 5(3): 1-76. Crabtree, K. 1969. Post-glacial zonation of limnic deposits in North Wales. Mitt. Internat. Verein. Limnol. 17: 165-171.

Crandell, D. R., D. R. Mullineaux and M. Rubin. 1975. Mount St. Helens volcano: Recent and future behavior. Science 187: 438-441.

Crisman, T. L. and D. R. Whitehead. 1975. Environmental history of Novey Lake, southwestern Indiana. Am. Midl. Nat. 93(1): 198-205. Curry, R. R. 1969. Holocene climate and glacial history of the central Sierra Nevada, California. In: United States Contributions to Quaternary Research. VIII Congress of the International Association for Quaternary Research. S. A. 
Schumm and W. C. Bradley, eds. Geol. Soc. Am. Special Paper No. 123.

Davis, G. E. and G. L. Larson. 1976. Sediment characteristics and the trophic status of four Oregon lakes. Completion Report, grant A-027-0RE, Water Resources Research Institute, Oregon State University, Corvallis, OR.

Davis, M. B. 1965. Phytogeography and palynology of the northeastern United States. In: Quaternary of the United States, H. E. Wright, ed. Princeton University Press, Princeton.

Davis, M. B. 1973. Pollen evidence of changing land use around the shores of Lake Washington. Northwest Science 47: 133-148.

Davis, R. B. and S. A. Norton. 1978.

Paleolimnological studies of human impact on lakes in the United States, with emphasis on recent research in New England. Pol. Arch. Hydrobiol. 25: 95-115.

Deevey, E. S. 1939. Studies on Connecticut lake sediments I. A postglacial climatic chronology for southern New England. Am. J. Sci. 237(10): $691-724$.

Deevey, E. S. 1942. Studies on Connecticut lake sediments III. The biostratonomy of Linsley Pond. Am. J. Sci. 240: 233-264 and 313-324. 
Deevey, E. S., D. S. Rice, P. M. Rice, H. H. Vaughan,

M. Brenner, M. S. Flannery. 1979. Mayan urbanism: Impact on a tropical karst

environment. Science 206: 298-306.

Edmondson, W. T. 1978. Formation of recent

laminations in sediment of Lake Washington.

Verh. Internat. Verein. Limnol. 20: 361 .

Faegri, K. and J. Iverson. 1975. Textbook of Pollen

Analysis, 3rd Edition. Hafner Press, New York.

Flanagan, F. J. (editor). 1976. Descriptions and

analysis of eight new U.S.G.S. rock standards.

U.S. Geological Survey Professional Paper No.

840 .

Franklin, J.F. and C. T. Dyrness. 1973. Natural

Vegetation of Oregon and Washington. USDA Forest

Service General Tachnical Report PNW-8. Pacific

Northwest Forest and Range Experiment Stateion,

Portland, $O R$.

Fryxell, R. 1965. Mazama and Glacier Peak volcanic

ash layers: Relative ages. Science 147:

$1288-1290$.

Glicker, J. 1981. Portland, Oregon Water Bureau.

Personal communication.

Gordon, G. E., K. Randle, G. G. Coles, J. B. Corliss,

M. H. Beeson and S. S. 0xley. 1968.

Instrumental activation analysis of standard 
rocks with high resolution gamma-ray detectors. Geochim. Cosmochim. Acta 32: 369-396.

Hansen, B. S. and D. J. Easterbrook. 1974. Stratigraphy and palynology of late Quaternary sediments in the Puget Sound region. Geol. Soc. Am. Bull. 85: 578-602.

Hansen, H. P. 1947. Post glacial forest succession, climate and chronology in the Pacific Northwest. Am. Phil. Soc. 37: 1-130.

Harris, G. P. and R. A. Vollenweider. 1982. Paleolimnological evidence of early eutrophication in Lake Erie. Can. J. Fish. Aquat. Sci. 39: 618-626.

Harris, S. L. 1976. Fire and Ice: The Cascade Volcanoes. The Mountaineers, Pacific Search Press, Seattie.

Harrison, B. 1892. Proclamation, June 17, 1892. Heinselman, M. L. 1973. Fire in the virgin forests of the Boundary Waters Canoe Area, Minnesota. Quat. Res. 3: $329-382$.

Helvey, J. D. 1980. Effects of a north central Washington wildfire on runoff and sediment production. Wat. Resour. Bull. 16(4): 627-634. Hemstrom, M. A. and J. F. Franklin. 1982. Fire and other disturbances of the forests in Mt. Rainier National Park. Quat. Res. 18(1): 32-51. 
Heusser, C. J. 1973. Environmental sequence following the Fraser advance of the Juan de Fuca lobe, Washington. Quat. Res. 3: 284-306.

Heusser, C. J. 1977. Quaternary palynology of the Pacific slope of Washington. Quat. Res. 8: $282-306$

Heusser, C. J. and L. E. Heusser. 1980. Sequence of pumiceous tephra layers and the late Quaternary environmental record near Mt. St. Helens. Science 210: 1007-1009.

Hitchcock, C. L. and A. Cronquist. 1973. Flora of the Pacific Northwest. University of Washington Press, Seattle.

Hongre, D. and A. H. Erlandsen. 1979. Shortening of surface cores during sampling. Hydrobiol. 65(3); $283-287$

Hustedt, F. 1930. Die SUsswasser-Flora Mitteleuropas, Heft 10: Bacillariophyta (Diatomeae). Jena, Verlag von Gustav Fischer.

Hustedt, F. 1942. Die Binnegewasser. In: G. Huber-Pestalozzi, ed. Das Phytoplankton des Susswassers. Band 16, Teil 2, Hylfte 2. 542p. Hutchinson, G. E. 1967. A Treatise on Limnology, Volume II. John Wiley and Sons, New York. Hutchinson, G. E. 1970. Ianula: An account of the history and development of the Lago di Monterosi, 
Latium, Italy. Trans. Am. Phil. Soc. 60 (4):

$1-178$.

Johnson, D. M. and J. 0. Dart. 1982. Variability of

Precipitation in the Pacific Northwest: Spatial and temporal characteristics. Completion Report A-050-0RE, Office of Water Resources Research. Water Resources Research Institute, Corvallis, OR.

Kapp, R. 0. 1969. How to Know Pollen and Spores. W. C. Brown Co., Dubuque.

Kilnam, P. 1971. A hypothesis concerning silica and the freshwater planktonic diatoms. Limnol. Oceanogr. 16 $(1): 10-18$.

Kimmel, B. L. 1978. An evaluation of recent sediment focusing in Castle Lake (California) using a volcanic ash layer as a stratigraphic marker. Verh. Internat. Verien. Limnol. 20: 393-400.

Kittleman, L. R. 1979. Tephra. Sci.Am. 241(6): $160-177$.

Klein, J., J. C. Lerman, P. E. Damon and E. K. Ralph. 1982. Calibration of radiocarbon dates. Radiocarbon 24(2): 103-150.

Kurenkov, I. I. 1966. The influence of volcanic ashfall on biological processes in a lake. Limnol. Oceanogr. 11: 426-429.

Larson, G. L., A. R. Abernethy and D. E. Allison. 1976. 
Chemical features of the recent sediments of a high-mountain lake. Arch. Hydrobiol. 78(4): $456-467$.

Laul, J. C. 1979. Neutron activation analysis of geological materials. Atomic Energy Rev. 17(3); $603-695$.

Legendre, L. and W. D. Watt. 1972. On a rapid technique for plankton enumeration. Ann. Inst. oceanogr. 48(2): $173-177$.

Livingstone, D. A. and R. L. Kendall. 1969.

Stratigraphic studies of east African lakes.

Mitt. Int. Ver. Theor. Angew. Limnol. 17:

$147-153$.

Lowe, R. L. 1974. Environmental requirements and pollution tolerance of freshwater diatoms. US Environmental Protection Agency, EPA-670/4-74-005

Lowe, R. L. 1975. Comparative ultrastructure of the values of some cyclotella species (Bacillariophyceae). J.Phycol. 14: 415-424.

Lund. J. G. W., C. Kipling, and E. D. Le Cren. 1958. The inverted microscope method of estimating algal numbers and the statistical basis of estimation by counting. Hydrobiol.11: 143-170. Mackereth, F. J.H. 1966. Some chemical observations on post-glacial lake sediments. Phil. Trans. 
Roy. Soc. B. 250: 165-213.

McAndrews, J. H., A. A. Berti and G. Norris. 1973.

Key to the Quaternary pollen and spores of the

Great Lakes region. Life Sci.Misc. Publ., R.

Ont. Mus.

McColl, J. G. and D. F. Grigal. 1975. Forest fire:

Effects on phosphorus movement to lakes. Science

188: $1109-1111$.

McFarland, B. H. and G. B. Collins. 1978. A key to

the species of the diatom genus cyclotella (Kutz)

Breb. based on new morphological data.

Manuscript of presentation to the 26th Annual

meeting of the North American Benthological

Society, Winnipeg, Canada.

McNabb, C. D. 1960. Enumeration of freshwater

phytoplankton concentrated on the membrane

filter. Limnol. Oceanogr. 5: 57-61.

Meyerhoff, R. D., G. L. Larson, G. E. Davis. 1978.

Sediment characteristics of three mountain lakes

with different trophic statuses. Arch.

Hydrobiol. 81 (4): $397-421$.

Miller, 1973. Miller vs. Mallery, Civil No. 73-609 (D.

Ore. filed July 18, 1973).

Moore, P. D. and J.A. Webb, 1978. An Illustrated

Guide to Pollen Analysis. Halsted Press, John

Wiley and Sons, New York. 
Murray, D. A. 1976. A light weight corer for sampling soft subaqueous deposits. Limnol. Oceanogr. 21(2): $\quad 341-344$.

Patrick, R. 1973. Use of algae, especially diatoms, in the assessment of water quality. In:

Biological Methods for the Assessment of Water Quality, ASTM STP 528, American Society for Testing and Materials.

Patrick, R. and C. W. Reimer. 1966. The Diatoms of the United States. Vol. 1. Acad. Nat. Sci. Philadelphia Monogr 13. $688 \mathrm{p}$.

Patrick, R. and C. W. Reimer. 1975. The Diatoms of the United States. Vol 2. Part I. Acad. Nat. Sci. Philadelphia, Monogr. 13, $213 \mathrm{p}$.

Pearlman, S. M. 1978. Bull Run: A Reserve and a Water System. Unpublished manuscript. Petersen, R. R. 1975. A paleolimnological study of the eutrophication of Lake Erie. Verh. Int, Verein. Limnol. 19: 2274-2283.

Priest, G. R. and B. F. Vogt, eds. 1982. Geology and geothermal resources of the Mt. Hood Area, Oregon. Oregon Department of Geology and Mineral Industries, Special Paper 14.

Public Law 58-206. 1904. An act for the protection of the Bull Run Forest Reserve and the sources of the water supply of the City of Portland, State 
of Oregon. 18 USC 1862 .

Public Law 95-200. 1977. An Act to provide improved authority for the administration of certain National Forest System lands in Oregon. 16 USC $482 b(1977)$.

Randle, K., G. G. Coles, and L. R. Kittleman. 1971. Geochemical and petrological characterization of ash samples from Cascade Range volcanoes. Quat. Res. 1(2): $261-282$.

Raymond, R. B. 1980. A brief history of the Portland Water System with emphasis on events in the Bull Run Reserve. Report to the Bull Run Advisory Committee, Water Quality Task Force, Portland, Water Bureau.

Rushforth, S. R., J. D. Brotherson, N. Fungladda and W. E. Evenson. 1981. The effects of dissolved heavy metals on attached diatoms in the Uintah Basin of Utah, USA. Hydrobiol. 83: 313-323. Schelske, C. M. S. Simmons and L. E. Feldt. 1975. Phytoplankton response to phosphorus and silica enrichments in Lake Michigan. Verh. Internat. Verein. Limnol. 19: 911-921.

Schindler, R. W., R. W. Newbury, K. G. Beaty, J. Prokopowich, T. Ruszczynski and J. A. Dalton. 1980. Effects of a windstorm and forest fire on chemical losses from forested watershed and on 
the quality of receiving streams. Can. J. Fish. Aquatic Sci. 37(3): 328-334.

Schulters, M. V. 1975. Lakes of Oregon, Volume 3:

Hood River, Multnomah, Washington and Yamhill

counties. US Geological Survey Open File

Reports.

Schulters, M. V. and D. G. Clifton. 1980. Mt. St. Helens volcanic ash fall in the Bull Run watershed, Oregon, March-June, 1980. US Geological Survey Circular 850-A.

Shannon and Wilson, Inc. 1961. Report on geology and engineering feasibility of increased storage at Bull Run Lake, Oregon. Report to the City of Portland.

Smol, J.P. and M. D. Dickman. 1981. The recent histories of three Canadian shield lakes: A paleolimnological experiment. Arch. Hydrobiol. 93(1): $83-108$.

Swain, A. 1973. A history of fire and vegetation in northeastern Minnesota. Quat. Res. 3: 383-396.

Swain, A. M. 1978. Environmental changes during the past 2000 years in north central Wisconsin: Analysis of pollen, charcoal and seeds from varved lake sediments. Quat. Res 10: 55-68.

Taylor, S. R. and A. J. R. White. 1965. Geochemistry of andesites and the growth of continents. 
Nature 208(3004): $271-273$.

Taylor, S. R. and A. J. T. White. 1966. Trace element abundances in andesites. Bulletin Volcanologique 29: $\quad 177-194$.

Terasmae, J. and N. C. Weeks. 1979. Natural fires as an index of paleoclimate. Can. Field Naturalist 93 (2): $116-125$.

Thatcher, E. M. 1976. Mammals of Bull Run. M.S. Thesis. Department of Biology, Portland State University, Portland, OR.

Tiedemann, A. R., J. D. Helvey and T. D. Anderson. 1978. Stream chemistry and watershed nutrient economy following wildfire and fertilization in eastern Washington. J. Env. Qual. 7(4):

$580-588$.

Tiedemann, A. R., J. D. Helvey and T. D. Anderson. 1979. Effects of Fire on Water. U.S.D.A. Forest service General Technical Report w0-10, September, 1979.

Tilman, D. and S. S. Kilham. 1976. Phosphate and silicate growth and uptake kinetics of the diatoms Asterionella formosa and Cyclotella meneghiniana in batch and semicontinuous culture. J.Phycol. 12(4): 375-383.

Tolonen, M. 1978. Palaeoecology of annually laminated sediments in Lake Ahvenainen, South Finland, I. 
Pollen and charcoal analyses and their relation

to human impact. Ann. Bot. Fennici 15: 177-208.

Tsukada, M. S. Sugita and D. M. Hibbert. 1981.

Paleoecology in the Pacific Northwest, I. Late

Quaternary vegetation and climate. Verh.

Internat. Verein. Limnol. 21: 730-737.

Tutin W. 1969. The usefulness of pollen analysis in

interpretation of stratigraphic horizons in both

late glacial and post glacial. Mitt. Internat.

Verein.Limnol.17: 154-164.

USDA Forest Service, Mt. Hood National Forest. 1979.

Bull Run Planning Unit Land Managment Plan:

Final Environmental Statement,

USDA-FS-FES(Adm) $-76-16$.

Wainerdi, R. E. and E. A. Uken. 1971. Modern Methods

of Geochemical Analysis. Plenum Press, New York.

Weaver, C. E. 1981. Department of Geology, Georgia

Institute of Technology, Atlanta. Personal

communication.

Wetzel, R. G. 1975. Limnology. H. B. Saunders Co.,

Philadelphia.

White, C. 1980. Geology and geochemistry of Mt. Hood

Volcano. In Priest and Vogt, eds., Geology and

geothermal resources of the Mt. Hood area,

Oregon. Oregon Department of Geology and Mineral

Industries, Special Paper No. 8. 
Willis, R. 1979. Portland Water Bureau. Personal communication.

Wise, W. S. 1969. Geology and petrology of the Mt. Hood area: A study of high Cascade volcanism. Geol. Soc. Am. Bul1.80: 969-1006.

Wollenberg, H. A., R. E. Bowen, H. R. Bowen and B. Strisower. 1979. Geochemical Studies of Rocks, Water and Gases at Mt. Hood, Oregon. Lawrence Berkely Laboratory LBL-7092, Oregon Department of Geology and Mineral Industry Open File Report $0-79-2$.

Wright, R. F. 1976. The impact of forest fire on the nutrient influxes to small lakes in northeastern Minnesota. Ecology 57: 649-663. 